\title{
Large-Scale Dynamics of the Meiyu-Baiu Rainband: Environmental Forcing by the Westerly Jet*
}

\author{
TAKEAKi SAMPe AND SHANG-PING XIE ${ }^{+}$ \\ International Pacific Research Center, SOEST, University of Hawaii at Manoa, Honolulu, Hawaii
}

(Manuscript received 10 March 2009, in final form 3 July 2009)

\begin{abstract}
Meiyu-baiu is the major rainy season from central China to Japan brought by a zonally elongated rainband from June to mid-July. Large-scale characteristics and environmental forcing of this important phenomenon are investigated based on a reanalysis dataset. The meiyu-baiu rainband is accompanied by a trough of sea level pressure, horizontal shears, and sharp moisture gradients near the surface, a westerly jet tilted northward with height, and large northeastward moisture transport from the south.

The analysis here reveals the westerly jet as an important culprit for meiyu-baiu. Along the rainband, mean ascending motion corresponds well with a band of warm horizontal temperature advection in the midtroposphere throughout summer. This adiabatic induction of upward motion originates from the advection of warm air by the westerlies from the eastern flank of the Tibetan Plateau. The ascending motion both induces convection and is enhanced by the resultant condensational heating. The westerly jet anchors the meiyu-baiu rainband also by steering transient eddies, creating periods conducive to convection through convective instability and adiabatic updrafts. Indeed, in meiyu-baiu, the probability distribution of convective instability shows large spreads and is strongly skewed, with a sharp cutoff on the unstable side resulting from the effective removal of instability by convection. Thus, active weather disturbances in the westerly waveguide explain a paradox that convection is active in the meiyu-baiu rainband while mean convective instability is significantly higher to the south over the subtropical North Pacific warm pool. In addition to the westerly jet, low-level southerly winds over eastern China between the heat low over Asia and the subtropical high pressure belt over the Pacific are another important environmental forcing for meiyu-baiu by supplying moisture. A conceptual model for meiyu-baiu is presented, and its implications for seasonal and interannual variations are discussed.
\end{abstract}

\section{Introduction}

Early summer climate of East Asia is characterized by a quasi-stationary rainband that extends from southeast China to Japan (e.g., Ninomiya and Murakami 1987; Tao and Chen 1987). This rainband brings the major rainy season, called meiyu in China and baiu in Japan, to these densely populated regions. The meiyu-baiu rainband displays large variability on time scales from hours to interannual, making it perhaps the single most important

\footnotetext{
* International Pacific Research Center School of Ocean and Earth Science and Technology Contribution Number 620/7775.

+ Additional affiliation: Department of Meteorology, University of Hawaii at Manoa, Honolulu, Hawaii.
}

Corresponding author address: Takeaki Sampe, IPRC, SOEST, University of Hawaii, 1680 East West Road, Honolulu, HI 96822. E-mail: takeaki@hawaii.edu climatic phenomenon of East Asia. Abnormally low rainfall in the meiyu-baiu season causes a shortage of water and affects socioeconomic activity. When meiyu-baiu is very active, on the other hand, torrential rain may occur, causing flooding and mudslides. For example, the 1998 Yangtze River flood caused 3004 deaths and displaced 14 million people, with a total of \$24 billion in economic loss.

In the Yangtze River valley of China and central Japan, meiyu-baiu commences in early to mid-June and ends in mid-July, during which a zonally elongated rainband covers China, Japan, and the northwestern Pacific along $30^{\circ}-40^{\circ} \mathrm{N}$ (Fig. 1a). Within this rainband, mesoscale disturbances develop accompanied by intense convection and heavy rain (e.g., Ninomiya and Shibagaki 2007). In this study, the meiyu-baiu rainband refers to the entire rainband including its eastward extension beyond Japan, while meiyu and baiu rainbands refer to the sections over China and Japan, respectively. Meiyubaiu is part of the East Asian summer monsoon. Major 

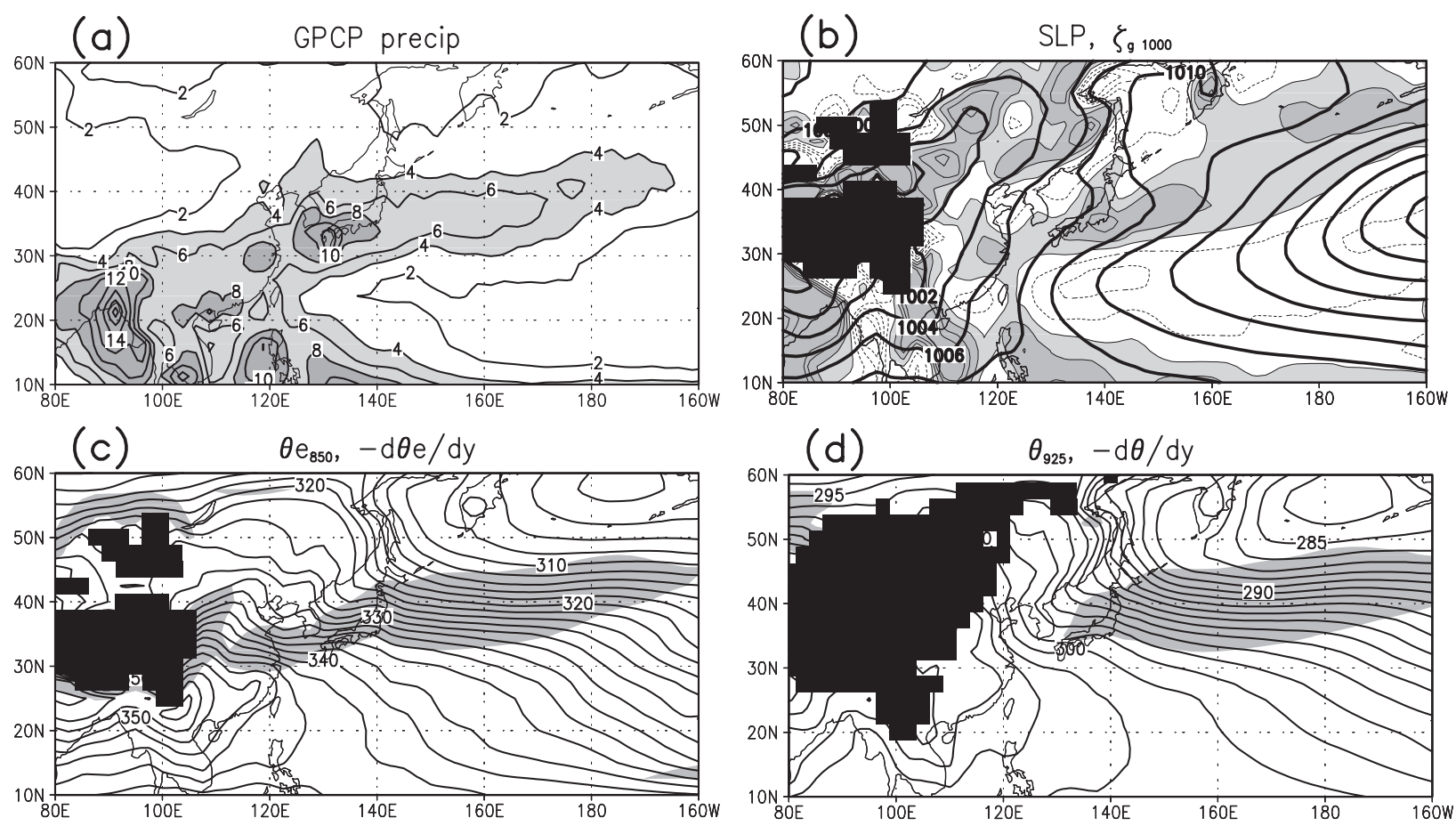

(e)

$\mathrm{q}_{925}$

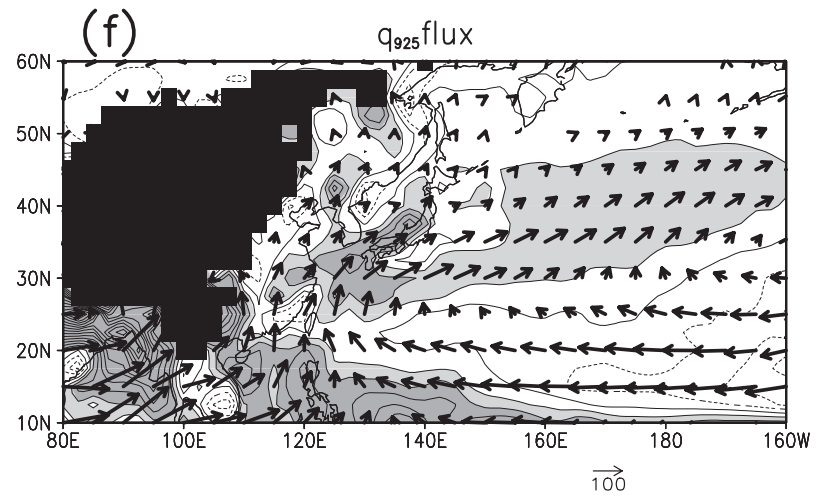

FIG. 1. Climatology in meiyu-baiu season (16 Jun-15 Jul). (a) GPCP precipitation [contour interval: $2 \mathrm{~mm}^{\text {day }}{ }^{-1}$, with light (dark) shading for 4-8 (>8 $\left.\mathrm{mm} \mathrm{day}^{-1}\right)$ ]. (b) Sea level pressure (thick lines at every $2 \mathrm{hPa}$ ) and relative vorticity of 1000-hPa geostrophic wind [thin lines at every $5 \times 10^{-6} \mathrm{~s}^{-1}$ with light (dark) shading for $0-5\left(>5 \times 10^{-6} \mathrm{~s}^{-1}\right)$. Topography above $1.5 \mathrm{~km}$ is black.] (c) Equivalent potential temperature at $850 \mathrm{hPa}$ (solid lines at every $2 \mathrm{~K}$ ) calculated following Bolton (1980), with shading where its equatorward gradient is greater than $1.2 \mathrm{~K}$ (deg lat) ${ }^{-1}$. (d) Potential temperature at $925 \mathrm{hPa}$ (solid lines at every $1 \mathrm{~K}$ ), with shading where its equatorward gradient is greater than $0.5 \mathrm{~K}$ (deg lat) ${ }^{-1}$. (e) Specific humidity at $925 \mathrm{hPa}$ (solid lines at every $1 \mathrm{~g} \mathrm{~kg}^{-1}$ ), with shading where its equatorward gradient is greater than $0.4 \mathrm{~g} \mathrm{~kg}^{-1}$ (deg lat) $)^{-1}$. (f) Horizontal moisture flux at $925 \mathrm{hPa}\left(\mathrm{arrows}_{\mathrm{g} \mathrm{kg}}^{-1} \cdot \mathrm{m} \mathrm{s}^{-1}\right.$ ) and its convergence (thin lines at every $1 \mathrm{~g} \mathrm{~kg}^{-1}$ day $^{-1}$ with light and dark shading for $1-2$ and $>2 \mathrm{~g} \mathrm{~kg}^{-1} \mathrm{day}^{-1}$ ). Negative contours are dashed.

rainfall first appears in the South China Sea (SCS), Indochina Peninsula, and Philippines around mid-May, and then migrates northward to the Yangtze River Valley and Japan to form the meiyu-baiu rainband. In mid-July the rainband abruptly migrates again to northern China and Korea to end meiyu-baiu (e.g., Ding and Chan 2005; Wang and LinHo 2002).

An extensive literature exists on meiyu-baiu (Akiyama 1973; Chen and Chang 1980; Kodama 1992; Ninomiya and Shibagaki 2007, and references therein). Several major reviews have recently been published, including Ding and Chan (2005), and monographs edited by Chang (2004) and Wang (2006). A brief summary of large-scale features of meiyu-baiu follows. The meiyu-baiu rainband forms on the northern boundary of a warm moist air mass in the subtropics. Moisture transport by the southwesterly flow along the western rim of the North Pacific subtropical high (NPSH) feeds the rainband (Akiyama 1973; Kodama 1992). The low-level southwesterly flow from the Indochina Peninsula and SCS is also an important source of 
moisture. Heavy rainfall is occasionally observed in the rainband, with midtropospheric warming and moistening as a consequence of active cumulus convection (Ninomiya 1980). The meiyu-baiu rainband is accompanied by characteristic frontal structures in the lower troposphere, which is called the meiyu-baiu front, and can be identified as sharp gradients in specific humidity and equivalent potential temperature (Ninomiya 1984) and as a horizontal wind shear line (Akiyama 1973). Unlike moisture, the low-level temperature gradient is weak over China and modest around Japan, so the meiyu-baiu front is different from the traditional warm/ cold front or "polar front" defined as the boundary between warm and cold air masses. Ninomiya (1984) pointed out that the baiu front is a "subtropical front" characterized by a thick moist layer with moist-neutral stratification on the south flank, with a sharp poleward decrease in moisture.

The meiyu-baiu onset is associated with a northward shift in the NPSH axis to about $25^{\circ} \mathrm{N}$ and the migration of the upper-level westerly jet over Eurasia to the north of the Tibetan Plateau. The jet is located on the northern flank of the Tibetan high centered around $25^{\circ}-30^{\circ} \mathrm{N}$ in the upper troposphere in response to intense monsoon convection (Tao and Chen 1987; $\mathrm{Li}$ and Yanai 1996). At the surface, a planetary-scale low is formed over the continent, accentuated by land-sea surface temperature contrast (Fig. 1b; Kawamura and Murakami 1998). This "heat low" leads to the low-level southerly wind on the east coast of the Eurasian continent (Xie and Saiki 1999) that provides moisture into the meiyu-baiu rainband. During meiyu-baiu, the upper-level subtropical jet core is located to the north of the rainband (Kodama 1993), while a lowlevel westerly jet is often observed to the south. Thus the westerly jet exhibits a northward tilt with height during active meiyu-baiu periods (Matsumoto et al. 1971; Chen and Chang 1980; Yamazaki and Chen 1993). The end of meiyu-baiu is characterized by an abrupt northward migration of the upper-level jet over East Asia and a northward advance of the NPSH over the northwestern Pacific (Ninomiya and Muraki 1986). These abrupt changes may be triggered by Rossby wave propagation from the west (Enomoto et al. 2003) and convective activity to the south. The late-July onset of convection over the subtropical northwestern Pacific is often associated with the meiyubaiu termination (Ueda et al. 1995), forming a meridional dipole resembling the Pacific-Japan (PJ) pattern of Nitta (1987). SST in the subtropical northwestern Pacific exceeds that in meiyu-baiu region, and it is puzzling that convection favors the latter over the former region until late July (Ueda et al. 2009).

Despite its importance, the large-scale climate dynamics of the meiyu-baiu rainband is poorly understood.
Many models simulate the synoptic meiyu-baiu rainband (Ninomiya et al. 2003; Lau and Ploshay 2009), but most of them have problems simulating the climatological rainband and its seasonal evolution. The difficulty stems from the long-standing problem of convective parameterization, a challenge of realistic representation of strong interaction between condensational heating in the rainband and circulation that feeds the moisture. Convection strongly depends on the low-level circulation, and convective heating in meiyu-baiu can induce a significant circulation response in turn (e.g., Yamazaki and Chen 1993), so examining the observed convection or low-level circulation is not enough to elucidate the cause of the whole meiyu-baiu system. It is important to isolate the external forcing that anchors the climatological rainband. Fundamental questions remain unanswered: what determines the position and timing of the meiyu-baiu rainband? Why is convection active in the meiyu-baiu rainband while SST and surface equivalent potential temperature (cf. Figs. 1c,d) are significantly larger to the south in the subtropics? Atmospheric general circulation models (AGCMs) have recently improved to a point that some of them, with increased resolution, begin to produce a meiyu-baiu-like, climatological rainband in early summer (Kawatani and Takahashi 2003). An understanding of meiyu-baiu climate dynamics is necessary to validate and interpret AGCM simulations, and to develop hypotheses to be tested in models.

Such a dynamical understanding must identify, other than internal convective feedback, external, large-scale environment that leads to meiyu-baiu formation. ${ }^{1}$ The NPSH is such an environmental forcing. It may be decomposed into an internal component interactive with meiyu-baiu convection and an external one of the planetary scale that results from land-sea thermal contrast. In the eastern Eurasian continent, low-level southerlies between the heat low on land and subtropical high over the ocean pushes rainfall poleward by moist advection (Xie and Saiki 1999; Chou et al. 2001; Wu and Liu 2003). In the western continent (e.g., North Africa), the opposite happens, and the rainband is pushed equatorward. Thus a simple land-sea contrast in the zonal direction maintains a continental-scale northeast tilt of rainfall, setting the stage for a subtropical rainband like meiyu-baiu to form over East

\footnotetext{
${ }^{1}$ Meiyu-baiu contains duality in its name of the environment in which it develops and the effect it entails. On the one hand, meiyu in Chinese and baiu in Japanese both mean "plum rain," indicating the coincidence of the rainy season with ripening plums. The term of meiyu-baiu, on the other hand, is also believed to originate from the Chinese character for mold (mei/bai), an unpleasant effect of prolonged humid, rainy conditions.
} 
Asia. The elevated heating effect of the Tibetan Plateau strengthens this tendency by forcing a cyclonic circulation in the lower troposphere (e.g., Liu et al. 2007).

The present study investigates large-scale dynamics of meiyu-baiu with a focus on its environmental forcing. By definition, an environmental forcing is external to and not strongly affected by the meiyu-baiu rainband. For example, low-level wind convergence south of Japan is not considered as external to the baiu rainband because of their mutual interactions. In search of environmental forcing, we note an empirical association of meiyu-baiu with the westerly wind jet aloft (Kodama 1993; Kawatani and Takahashi 2003). Our analysis shows that this association is not coincidental. The warm advection from the eastern Tibetan Plateau by the wind jet and disturbances that the jet steers are conducive to convection. Compared to studies before the 1990s, which were based on station observations or coarseresolution forecast models, our study benefits from a newly released atmospheric reanalysis that uses a dynamical model to assimilate ever-increasing amounts of observations, both in situ and from satellite. The new meiyu-baiu climatology calculated from this reanalysis is a byproduct that will be useful for future studies.

Mesoscale features of meiyu-baiu, though important for heavy rain, are beyond the scope of the present study. Meiyu-baiu as a weather phenomenon on meso-/ synoptic scales has been studied extensively, but there is a need to develop a climate-dynamical framework to understand the rainband as a climatological phenomenon. Our effort to isolate environmental forcing from internal convective feedback is one such attempt. It is common that the weather and climatological aspects of the same phenomenon are governed by quite distinct dynamics. For example, individual midlatitude winter storms grow into large amplitudes and are highly nonlinear, but storm track variability can often be represented by linear dynamics and responds to slow SST forcing from the tropics (e.g., Jin et al. 2006; Gritsun and Branstator 2007).

The rest of this paper is organized as follows. Section 2 describes the datasets and the model used in this study. Section 3 provides an overview of the meiyu-baiu rainband and associated circulations based on the reanalysis. Section 4 explores an adiabatic mechanism for inducing ascending motion along the meiyu-baiu rainband by midtropospheric temperature advection. Section 5 investigates the role of high-frequency disturbances along the jet in activating convection. Section 6 uses a linear model to explore the downstream development of convection along the westerly jet, a possible link between meiyu and downstream baiu. Section 7 is a summary and presents a conceptual model for meiyu-baiu.

\section{Data and model}

The main dataset used in this study is the Japanese 25-year Reanalysis (JRA-25), an atmospheric reanalysis that uses a recent numerical assimilation and forecast system of the Japan Meteorological Agency (JMA) (Onogi et al. 2007) as a joint project between the JMA and the Central Research Institute of Electric Power Industry, Japan. We use the 6-hourly data mapped on a $2.5^{\circ}$ grid on the standard pressure levels, while the original reanalysis was performed at a resolution of triangular truncation at wavenumber 106 (T106, equivalent to a grid spacing of $\sim 120 \mathrm{~km}$ ) and 40 vertical layers. The dataset covers 26 years from 1979 to 2004. JRA-25 shows good performance in capturing precipitation in East Asia and the tropics (Onogi et al. 2007). A prognostic ArakawaSchubert cumulus parameterization scheme is adopted in the model to represent convection. We use the 6-hourly accumulated convective and large-scale precipitation rate of JRA-25. Compared to Global Precipitation Climatology Project (GPCP) merged pentad-mean precipitation (Huffman et al. 1997), the JRA-25 total precipitation is generally smaller in the midlatitudes and larger in the subtropics in summer East Asia (not shown).

The linear baroclinic model (LBM) used in this study is based on the primitive equations linearized about the observed climatology of monthly mean fields. A detailed description of the LBM is found in Watanabe and Kimoto $(2000,2001)$. We use a version with a resolution of T42 with 20 vertical sigma levels (T42 L20). The model is forced with prescribed diabatic heating and solved with time integration. The vertical profile of the heating varies in space, based on the sum of convective and large-scale condensation heating from the JRA-25 monthly climatology (modified in the lowest $1.5 \mathrm{~km}$ so that it vanishes at the surface). The vertical maximum of the JRA-25 heating in June at $29^{\circ} \mathrm{N}, 129^{\circ} \mathrm{E}$ is, for example, about $6 \mathrm{~K} \mathrm{day}^{-1}$ at $450 \mathrm{hPa}$, typical of deep convection. The heating along the baiu rainband begins to decrease eastward east of Japan.

\section{Meiyu-baiu climatology}

This section describes the 26-year climatology (from 1979 to 2004) of the meiyu-baiu front and rainband as presented in Fig. 1. Though descriptions of meiyu-baiu in its active periods can be found in many previous studies, we touch on the climatology based on the recent reanalysis to facilitate dynamical diagnosis in subsequent sections. We choose 16 June to 15 July as the core meiyu-baiu season, though the start and end dates of the rainy season vary from one year to another (e.g., Table 3.2 of Tao and Chen 1987). These dates tend to lag with increasing latitude; the rainy season begins earlier 
in mid-May and ends in late June over southern China, Taiwan, and Okinawa. ${ }^{2}$ In GPCP precipitation (Fig. 1a), the meiyu-baiu rainband extends from the Yangtze River valley of China $\left(\sim 30^{\circ} \mathrm{N}\right)$ through central Japan toward the central North Pacific around $40^{\circ} \mathrm{N}$. South of the baiu rainband, there is a wedge of suppressed precipitation in the subtropics $\left(\sim 25^{\circ} \mathrm{N}\right.$, Fig. 1a), which corresponds to the axis of the NPSH as seen in the sea level pressure (SLP) field (Fig. 1b). Over the Eurasian continent, a planetary-scale surface low is formed, with southerly winds prevailing along the east coast. A SLP trough around the meiyu-baiu rainband is weak, while positive low-level relative vorticity due to horizontal wind shear traces the rainband well (Fig. 1b; Akiyama 1973). A surface high over the Sea of Okhotsk is not conspicuous, while it occasionally intensifies on submonthly time scales (Nakamura and Fukamachi 2004).

Figures $1 \mathrm{c}$,e show the $850-\mathrm{hPa}$ equivalent potential temperature $\left(\theta_{e 850}\right)$ and $925-\mathrm{hPa}$ specific humidity. The meiyu-baiu rainband represents a sharp front with large gradients in these fields. In contrast, the $925-\mathrm{hPa}$ potential temperature exhibits weak meridional gradients west of $120^{\circ} \mathrm{E}$ (Fig. 1d); the meiyu front over China is not a low-level baroclinic zone. The low-level meridional temperature gradient is large east of Japan around $35^{\circ}-40^{\circ} \mathrm{N}$ (Fig. 1d), sustained by a large SST gradient along the oceanic frontal zone in the Kuroshio/Oyashio Extension (KOE) region (Nakamura and Kazmin 2003). The meiyu-baiu front does not correspond well with any particular value of $\theta_{e 850}$ or specific humidity, raising questions about the concept of an air mass with homogeneous properties (Saito 1966).

Figure 1f shows horizontal moisture flux and its convergence. Moisture fluxes from the tropical Indian Ocean and North Pacific meet and turn northward around the SCS, then converge into the meiyu-baiu rainband to sustain copious precipitation. A comparison of Figs. 1b and $1 \mathrm{f}$ indicates the importance of the southerly flow on the western flank of the NPSH for the moisture transport. The LBM experiment in the appendix shows that the low-level southerlies are not forced by latent heating of the meiyu-baiu rainband and should be considered as an environmental field resulting from land-sea thermal constant, the Tibetan heating, and South Asian monsoon convection (e.g., Xie and Saiki 1999; Kato 1989).

\section{a. Vertical structure}

Figure 2 shows meridional sections of zonal wind, vertical velocity, and ageostrophic component of the

\footnotetext{
${ }^{2}$ The rainy season over these regions is sometimes referred to as "pre-summer rainy season" or simply "meiyu/baiu" in the literature.
}
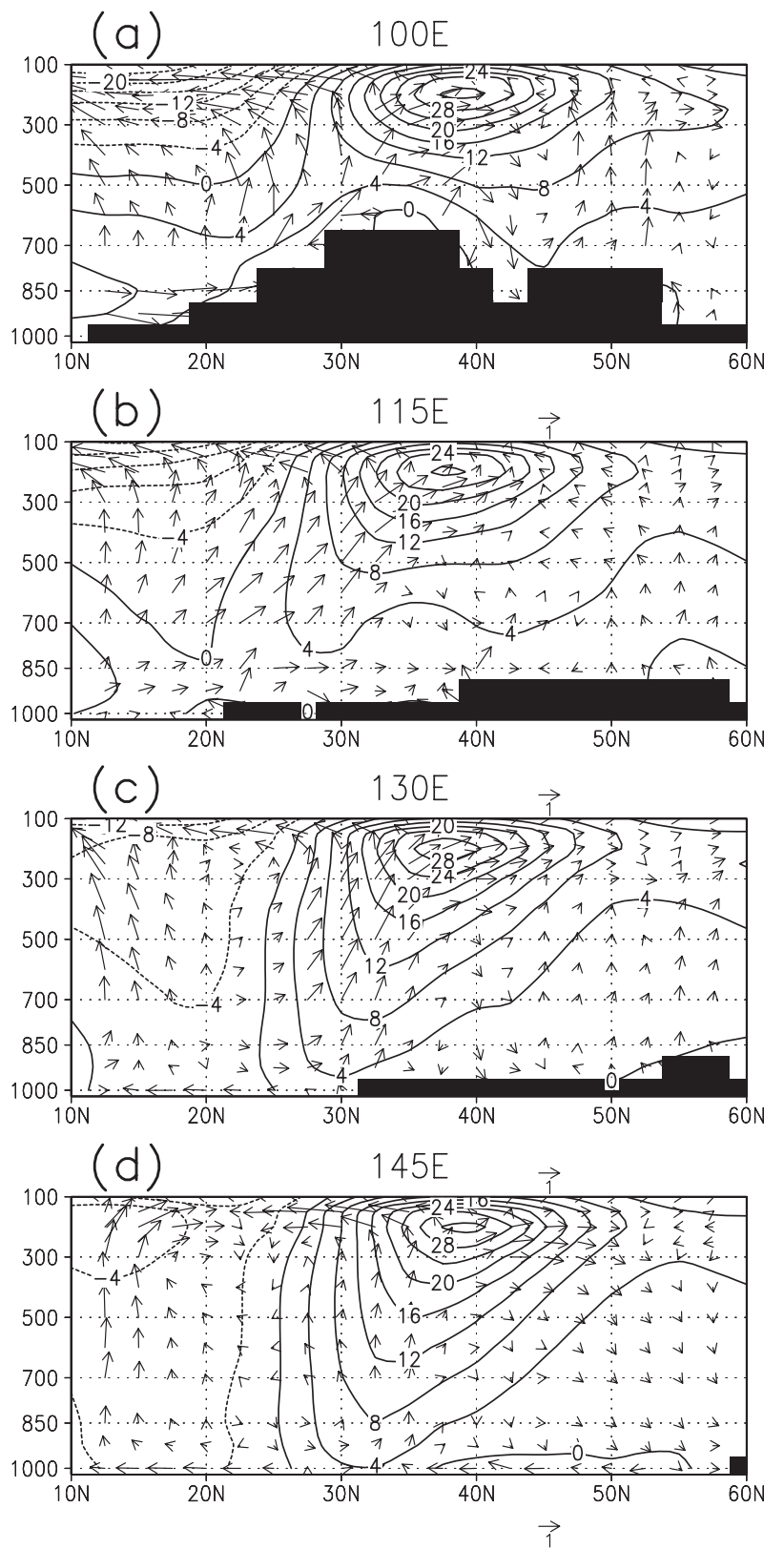

FIG. 2. Meridional section of climatological-mean zonal wind speed (contours: every $4 \mathrm{~m} \mathrm{~s}^{-1}$ ) and the meridional and vertical components of ageostrophic wind (arrows; units: $\mathrm{m} \mathrm{s}^{-1}$ and $\mathrm{Pa} \mathrm{s}^{-1}$, respectively; vertical component is multiplied by 20) in meiyu-baiu season at (a) $100^{\circ}$, (b) $115^{\circ}$, (c) $130^{\circ}$, and (d) $145^{\circ}$ E. Negative contours are dashed. Black area indicates topography.

meridional wind. While the upper-level jet core is located at $37^{\circ}-40^{\circ} \mathrm{N}$, the low-level jet axis is located about $10^{\circ}$ to the south, just slightly south of the meiyu-baiu rainband (Figs. 2b-d). This northward tilt of the westerly jet axis results from diabatic heating in the meiyu-baiu rainband, as elaborated with LBM in the appendix. At $100^{\circ} \mathrm{E}$ (upstream of the rainband), the low-level westerly wind is 
weak around $30^{\circ} \mathrm{N}$ and the upper-level westerly axis is to the north of the Tibetan Plateau around $40^{\circ} \mathrm{N}$ (Fig. 2a). At $115^{\circ} \mathrm{E}$, the low-level westerly wind has a local maximum around $28^{\circ} \mathrm{N}$ near the meiyu rainband (Fig. $2 \mathrm{~b}$ ). The low-level jet axis is accompanied by the southerly ageostrophic flow and the jet intensifies eastward (Figs. 2b-d), suggesting that the low-level jet is sustained by the eastward Coriolis acceleration on the ageostrophic southerlies, rather than by the vertical momentum transfer by cumulus convection. ${ }^{3}$ At $130^{\circ} \mathrm{E}$, the low-level ageostrophic flow converges and ascends at the rainband, with a single tilted jet with its upper-level axis to the north and low-level axis to the south (Figs. 2c,d). This low-level jet transports a large amount of moisture eastward (Fig. 1f) and is regarded as essential for the maintenance of the baiu rainband and its extension (Ninomiya and Murakami 1987). The tropospheric jet displays a northward seasonal migration from May to August. After mid-July, the tilt of the jet axis becomes inconspicuous (not shown), consistent with the weakening of convective heating.

Figure 3 shows a meridional section of equivalent potential temperature $\left(\theta_{e}\right)$ at $130^{\circ} \mathrm{E}$. The meridional $\theta_{e}$ gradient in the mid- and lower troposphere is strong in the meiyu-baiu rainband and slightly to the north. It is notable that the vertical $\theta_{e}$ gradient is generally small there, which may result from active convection that neutralizes moist instability (Ninomiya 1980). South of the meiyu-baiu rainband, $\theta_{e}$ increases equatorward at the surface but remains nearly constant in the midtroposphere. Sections 4 and 5 explain why the meiyubaiu rainband is favored for convection despite larger convective instability in $\theta_{e}$ farther to the south over the subtropical North Pacific (Fig. 1c).

\section{b. Seasonal march}

Figure 4 (left) shows the seasonal march of SLP and precipitation, while Figs. 5a and 5b show the latitudetime section of precipitation over eastern China and western Japan, respectively. Around $30^{\circ} \mathrm{N}$, meiyu-baiu precipitation starts in early June and gradually shifts northward, then abruptly weakens after mid-July (Figs. 5a,b) except over Korea (Fig. 4c). The front of low-level equivalent potential temperature exhibits a similar

\footnotetext{
${ }^{3}$ In heavy rainfall events, Matsumoto et al. (1971) and Akiyama (1973) suggested that convective vertical momentum transfer is important for the supergeostrophic low-level jet. In the long-term mean, however, the zonal wind is close to geostrophy and the contribution of vertical momentum transfer seems insignificant. Westerly acceleration by the vertical momentum transfer implies a northerly ageostrophic wind to maintain the thermal wind balance, inconsistent with Fig. 2.
}

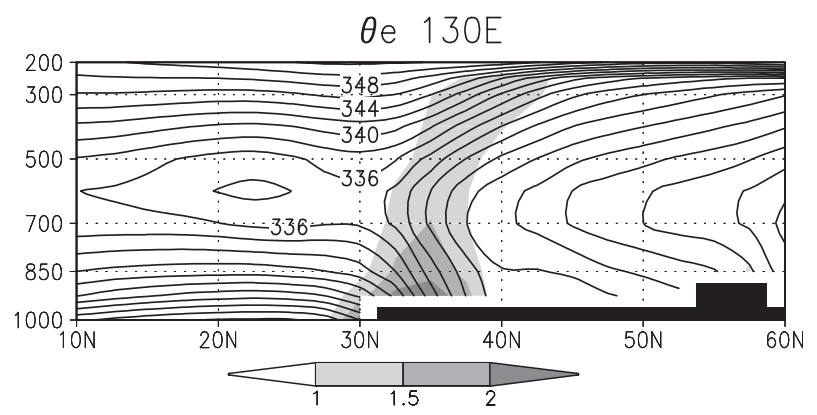

FIG. 3. As in Fig. 2c but for equivalent potential temperature (solid lines at every $2 \mathrm{~K}$ ). Shading denotes its equatorward gradient $\left[\mathrm{K}(\mathrm{deg} \text { lat })^{-1}\right]$.

northward migration and mid-July weakening (not shown). The axis of the NPSH migrates northward from $\sim 20^{\circ} \mathrm{N}$ in May to $\sim 25^{\circ} \mathrm{N}$ in the meiyu-baiu season, and farther to $30^{\circ}-35^{\circ} \mathrm{N}$ after mid-July, in step with the rainband (cf. Murakami and Matsumoto 1994). Previous studies suggest that NPSH variability over the northwestern Pacific is associated with convective activity over the SCS and/or east of the Philippines ( $\mathrm{Lu}$ and Dong 2001; Nitta 1987; Ueda et al. 1995; Kosaka and Nakamura 2006). The SLP trough along the rainband deepens in June between $130^{\circ}$ and $160^{\circ} \mathrm{E}$ and almost disappears after mid-July (Figs. $4 \mathrm{a}-\mathrm{c}$ ). The ascent in the rainband is associated with cyclonic vorticity at the surface, which is consistent with the trough formation.

The presence of the subtropical jet has been regarded as one of the requisites for the meiyu-baiu rainband in empirical studies (e.g., Kodama 1993). Figure 4 (right) shows the seasonal march of $500-\mathrm{hPa}$ wind and geopotential height. Before mid-June, the midtropospheric jet splits around the Tibetan Plateau, merges near western Japan, and runs east-northeastward (Fig. 4d). From May to June, low-level baroclinicity weakens around China and Japan, so the polar front appears far north in Siberia (Ninomiya 1984). In the meiyubaiu season, the southern branch of the jet diminishes (Fig. 4e; Murakami 1958). After mid-July, the jet migrates north to $\sim 45^{\circ} \mathrm{N}$ over the northwestern Pacific and runs zonally with little undulation throughout the troposphere (Figs. 4f, 5c, 5d), marking the end of meiyubaiu. In contrast to the diffluent $500-\mathrm{hPa}$ jet, the $200-\mathrm{hPa}$ jet over Eurasia appears as a single jet on the northern flank of the Tibetan high and shifts northward gradually during meiyu-baiu (not shown).

\section{Induction of upward motion in meiyu-baiu}

This section examines what induces upward motion in the meiyu-baiu rainband. Upward motion is associated 

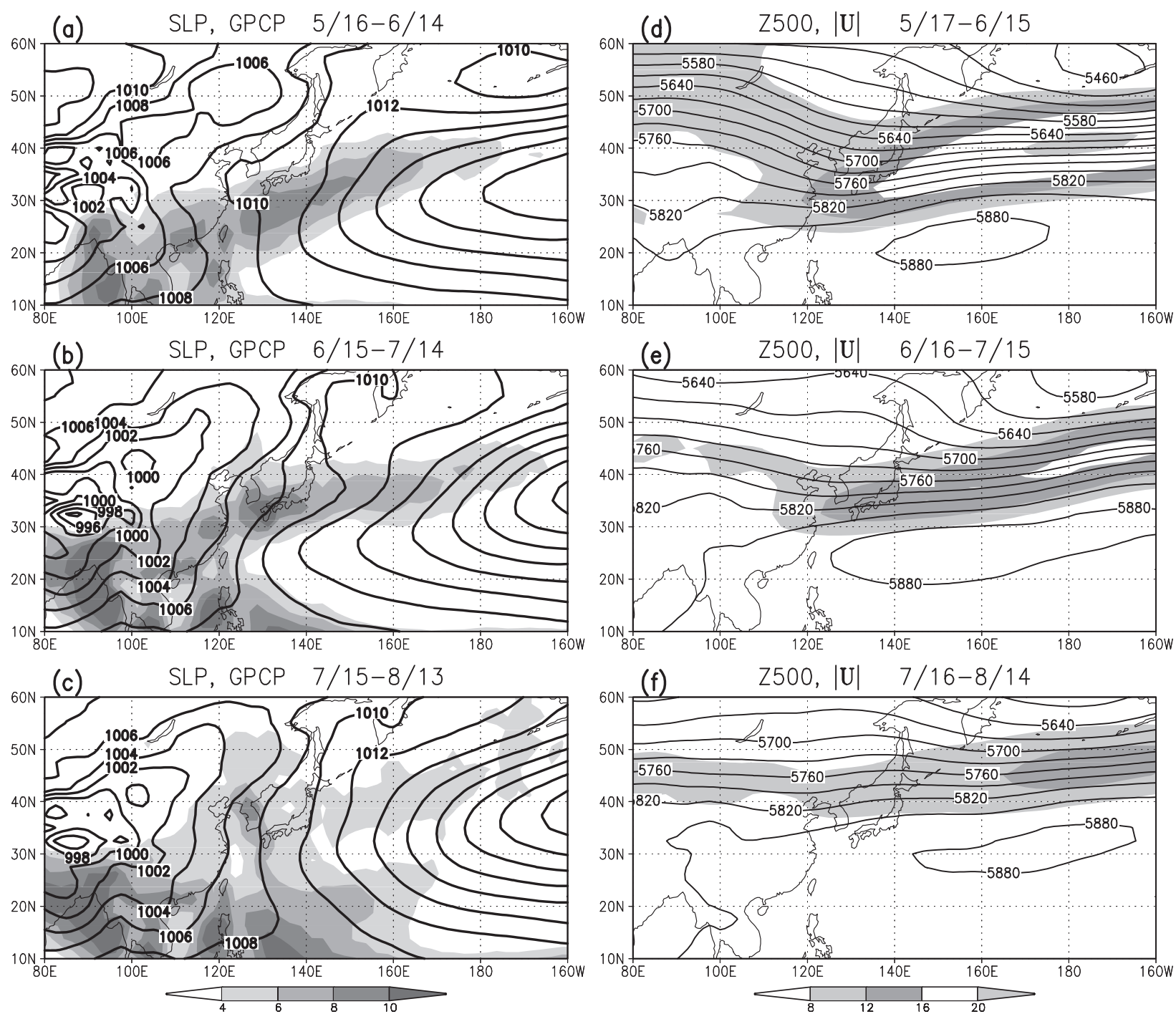

FIG. 4. Sea level pressure (solid lines at every $2 \mathrm{hPa}$ ) and GPCP precipitation (mm day ${ }^{-1}$, shading) for (a) $16 \mathrm{May}-14 \mathrm{Jun}$, (b) $15 \mathrm{Jun}-$ $14 \mathrm{Jul}$, and (c) $15 \mathrm{Jul}-13 \mathrm{Aug}$; (d)-(f) 500-hPa geopotential height (solid lines at every $30 \mathrm{~m}$ ) and mean wind speed (m s${ }^{-1}$, shading). In (d)-(f) the period is shifted by one day.

with heating, which in turn induces a couplet of a lowlevel trough and upper-level ridge. To avoid this complication by the convective feedback, we investigate the thermodynamic balance at the midtroposphere where the horizontal wind/geopotential response to meiyubaiu heating is small (see the appendix).

\section{a. Thermodynamic balance}

Following Rodwell and Hoskins (2001), we consider the relative importance of temperature advection and local diabatic heating in the thermodynamic energy equation in pressure coordinates

$$
\frac{\overline{\partial T}}{\partial t}=\frac{\bar{Q}}{C_{p}}-\left(\frac{p}{p_{0}}\right)^{R / C_{p}} \bar{\omega} \frac{\partial \bar{\theta}}{\partial p}-\overline{\mathbf{v}} \cdot \nabla_{p} \bar{T}-\left(\frac{p}{p_{0}}\right)^{R / C_{p}} \overline{\omega^{\prime} \frac{\partial \theta^{\prime}}{\partial p}}-\overline{\mathbf{v}^{\prime} \cdot \nabla_{p} T^{\prime}},
$$

$$
\begin{array}{llll}
\text { A } & \text { B } & \text { C } & \text { D }
\end{array}
$$

$\mathrm{E}$

where the overbar denotes the time mean, the prime signifies a deviation from the time mean, $Q$ is dia- batic heating/cooling, $p_{0}$ a standard constant pressure $(=1000 \mathrm{hPa})$, and other notations are standard. The 

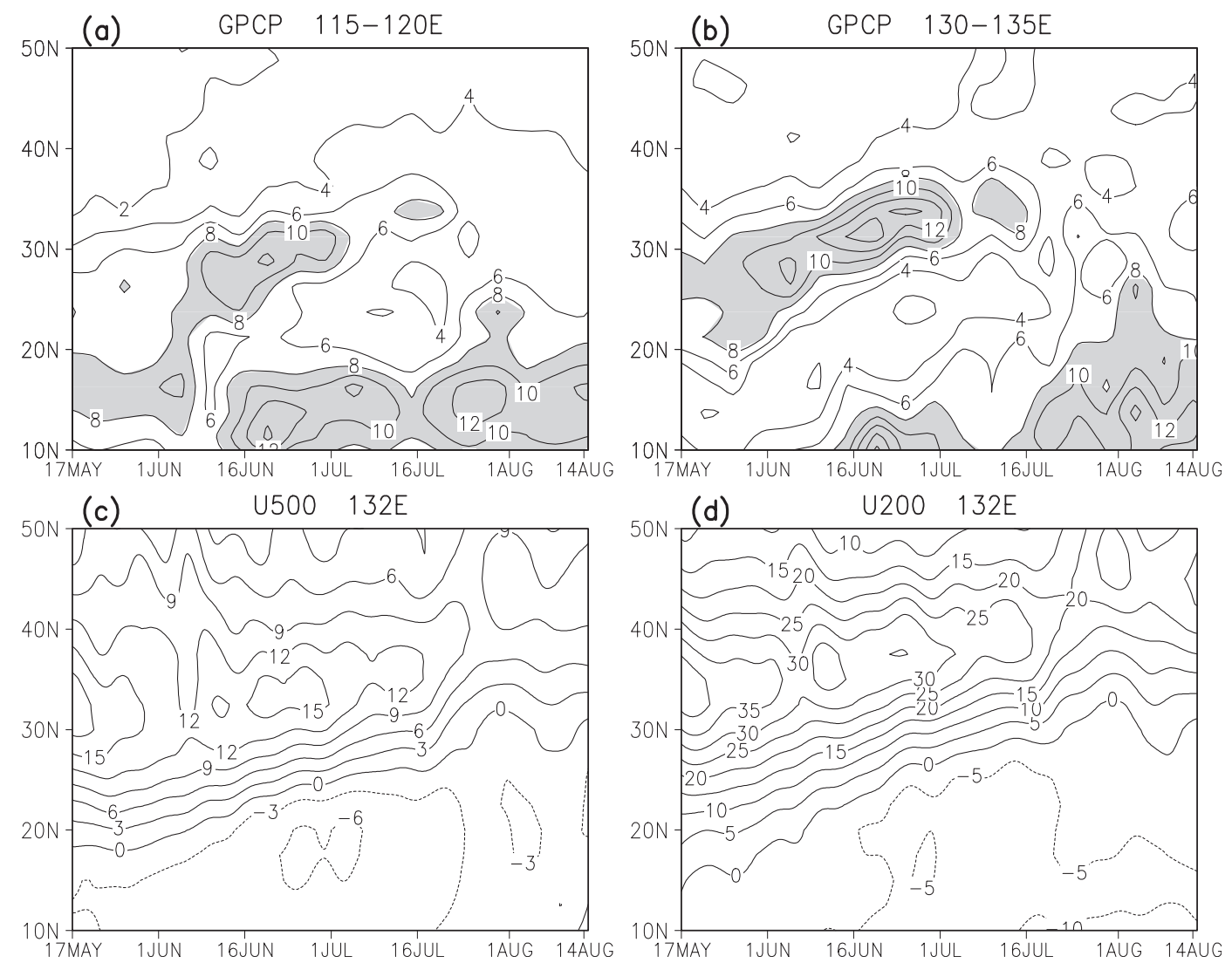

FIG. 5. Latitude-time sections of GPCP precipitation and westerly wind speed. Precipitation averaged at (a) $115^{\circ}-$ $120^{\circ} \mathrm{E}$ and (b) $130^{\circ}-135^{\circ} \mathrm{E}$ (contours at every $2 \mathrm{~mm} \mathrm{day}^{-1}$, shaded for values larger than $8 \mathrm{~mm} \mathrm{day}^{-1}$ ); (c) $500-\mathrm{hPa}$ westerly wind at $132^{\circ} \mathrm{E}$ (every $3 \mathrm{~m} \mathrm{~s}^{-1}$ ); (d) $200-\mathrm{hPa}$ westerly wind at $132^{\circ} \mathrm{E}$ (every $5 \mathrm{~m} \mathrm{~s}^{-1}$ ).

effects of subgrid-scale motions, such as vertical redistribution of heat by convection, is included in term B. On the seasonal time scale, the temperature tendency term (A) is negligible. The transient terms (E and F) are small in summer because transient wave activity over the North Pacific weakens rapidly from spring to summer (cf. Nakamura 1992). Thus, the thermodynamic balance is attained mainly by the diabatic forcing term (B), the vertical advection term $(\mathrm{C})$, and the horizontal advection term (D). In the tropics, the predominant balance is between B and C. Indeed, comparison of Figs. 4, 6, and 7 shows a close correspondence between mean ascent and precipitation, but not always with the horizontal temperature advection.

Figure 6a shows the horizontal advection of temperature $(-\mathbf{v} \cdot \nabla T)$ at $500 \mathrm{hPa}$, along with mean upward velocity in the core meiyu-baiu season. The advection is calculated from 6-hourly data before averaging over 26 years. The region of upward motion along the meiyubaiu rainband closely follows the region of positive (warm) temperature advection over the Yangtze River valley of China $\left(\sim 30^{\circ} \mathrm{N}\right)$ to the central Pacific around $40^{\circ} \mathrm{N}$. To the north of the rainband, upward motion is not seen over northern China to the Sea of Okhotsk, where negative (cold) temperature advection exists. Figures 7a,c show the seasonal march of the temperature advection and vertical velocity. Again, there is a remarkable correspondence between the warm advection and upward motion north of $25^{\circ} \mathrm{N}$ along the meiyu-baiu rainband that migrates northward from May to August. In late May to early June, cold advection over northern China and Korea coincides with descent. In late July to early August, warm advection over Korea and the central Pacific around $40^{\circ} \mathrm{N}$ coincides with ascent (Figs. 7a,c). The close correspondence of the temperature advection with the vertical velocity field indicates the importance of warm advection for the meiyu-baiu formation. Indeed, the rainband is collocated with the band of strong ascent in reanalysis (cf. Figs. 4a-c).

In the meiyu-baiu rainband, the diabatic forcing (B) and horizontal advection terms $(\mathrm{D}+\mathrm{F})$ are of the same sign and together balance the vertical advection term (C) (Figs. 4a-c and 6a, 7a, 7c). The diabatic heating 

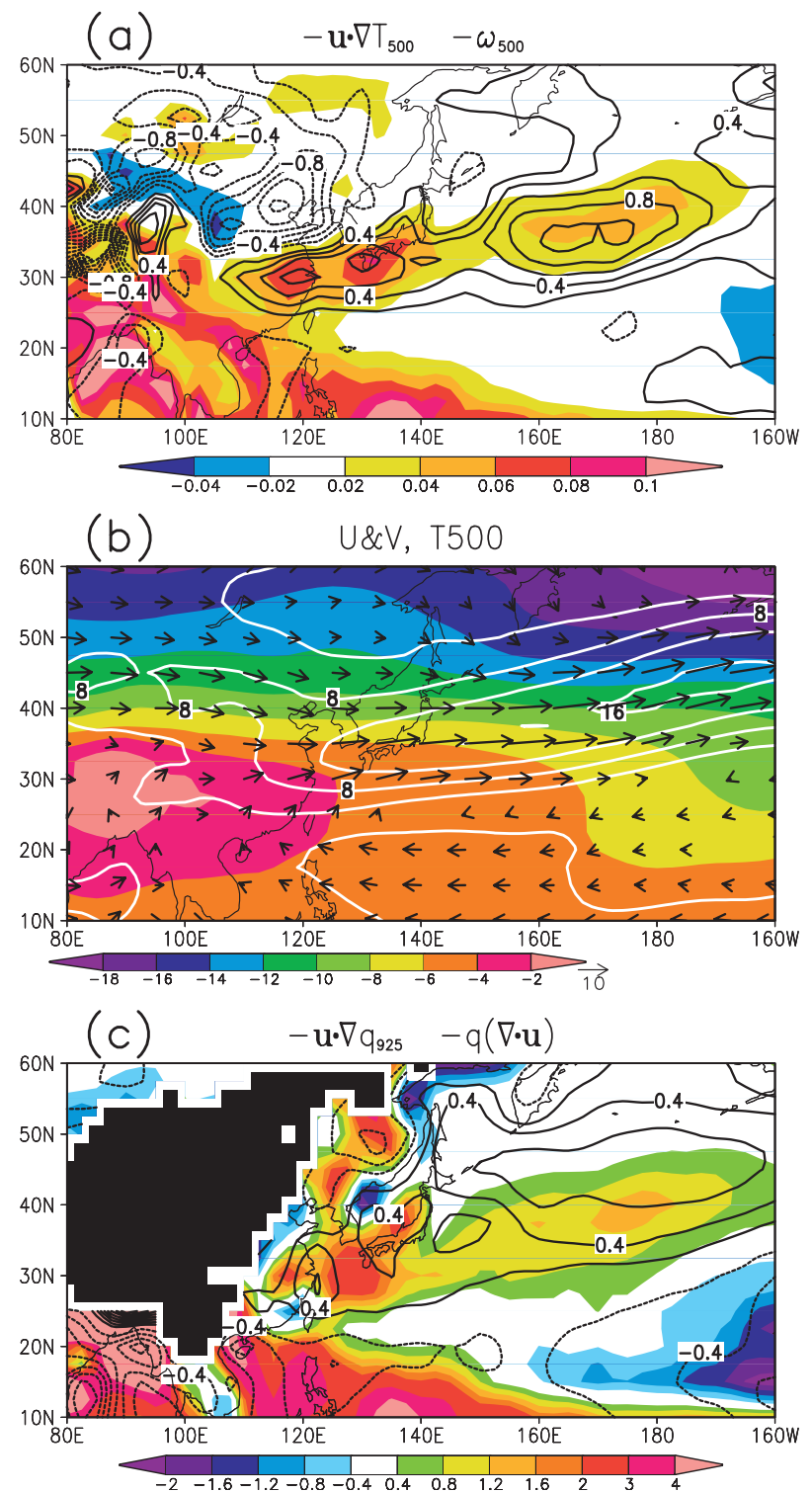

FIG. 6. (a) The 500-hPa horizontal advection of temperature (black lines at every $0.2 \mathrm{~K} \mathrm{day}^{-1}$ ) and upward vertical pressure velocity (color, $\mathrm{Pa} \mathrm{s}^{-1}$ ); (b) 500-hPa mean horizontal wind (arrows) and its speed (white lines at every $4 \mathrm{~m} \mathrm{~s}^{-1}$ ), with $500-\mathrm{hPa}$ temperature $\left({ }^{\circ} \mathrm{C}\right.$, color); (c) horizontal advection of $925-\mathrm{hPa}$ specific humidity (black lines at every $0.2 \mathrm{~g} \mathrm{~kg}^{-1}$ day $^{-1}$ ) and moisture flux convergence due to 925 -hPa horizontal velocity convergence $\left(\mathrm{g} \mathrm{kg}^{-1}\right.$ day ${ }^{-1}$, color). Negative contours are dashed and zero lines omitted.

strongly interacts with upward motion, and it is difficult to identify causality between them. In contrast, the warm horizontal advection does not result from local diabatic heating, as the LBM response to the meiyubaiu heating shows little local response in wind at $500 \mathrm{hPa}$ (see the appendix). Rather, the warm advection is set by a larger-scale environment, as shown in section $4 \mathrm{c}$. Thus a part of the upward motion is adiabatically induced by an external forcing, namely the warm horizontal advection. The close correspondence between the warm advection and upward motion leads us to propose a hypothesis that the externally induced ascent helps trigger convection by lifting air parcels, the resultant diabatic heating reinforces upward motion, and the convection-circulation feedback intensifies the meiyubaiu. From a hydrological cycle perspective, low-level wind convergence associated with the upward motion supplies much of the moisture for precipitation and is much larger than moisture advection (Fig. 6c), illustrating the importance of the interaction between upward motion and precipitation/diabatic heating. The feedback process between the diabatic heating and low-level circulation in the meiyu frontogenesis is recognized in the literature (Cho and Chen 1995; Chen et al. 2003).

Rodwell and Hoskins (2001) suggest estimating the fraction of ascent directly associated with adiabatic motion (on sloping isentropic surfaces) with the ratio of horizontal to vertical temperature advection $(-D / C)$. Our analysis indicates that this ratio along the meiyu-baiu rainband at $500 \mathrm{hPa}$ varies from $0.2 \sim 0.4$ over the Yangtze River valley and western Japan, to $0.6 \sim 0.7$ between $150^{\circ} \mathrm{E}$ and $180^{\circ}$. Smaller ratios over China and Japan indicate a strong "diabatic enhancement" of ascent due to convective feedback: active convection triggered by the advection-induced ascent releases large latent heat that enhances the ascent diabatically. Large ratios in the baiu extension suggest a much weaker convective feedback on the ascent induced through warm advection.

\section{b. Convective instability}

The regional difference in the above ratio of "adiabatic ascent" is consistent with that in convection and convective instability of the lower troposphere. Convective precipitation (Fig. 8a) is large in the western portion of the meiyu-baiu rainband, suggesting strong diabatic enhancement of ascent. In the baiu extension east of Japan (cf. Fig. 1a), convection is inactive, and consistently horizontal warm advection accounts for a large part of ascent. Because of weaker convection and diabatic enhancement, the observed ascent is much weaker in the eastern than the western portion of the rainband, despite a larger warm advection (Fig. 6a). Figure $8 \mathrm{a}$ also shows the vertical gradient of equivalent potential temperature $\left(\theta_{e}\right)$ between the $925-\mathrm{hPa}$ and 600-hPa levels, with a larger value indicating a more unstable atmosphere. The convective precipitation occurs exclusively where the vertical $\theta_{e}$ gradient is positive, indicating the importance of convective instability. The convective instability index is large in the tropics and decreases poleward, a tendency set by SST (dashed lines). As the baiu rainband extends east of Japan, the 
(a) $\quad-u \cdot \nabla T_{500}-\omega_{500} \quad 5 / 17-6 / 15$

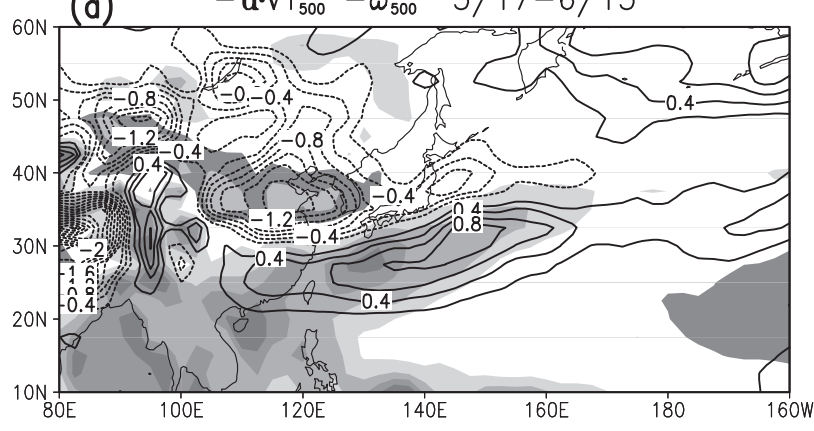

(c) $-\mathrm{u} \cdot \nabla \mathrm{T}_{500}-\omega_{500} \quad 7 / 16-8 / 14$

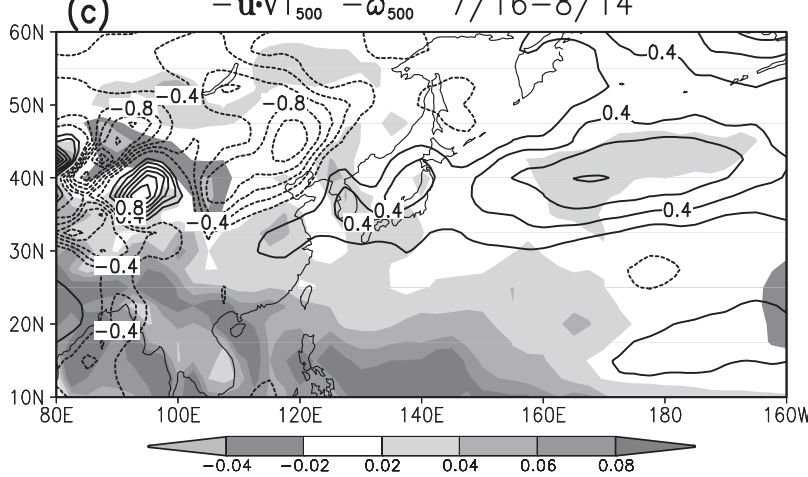

(b)

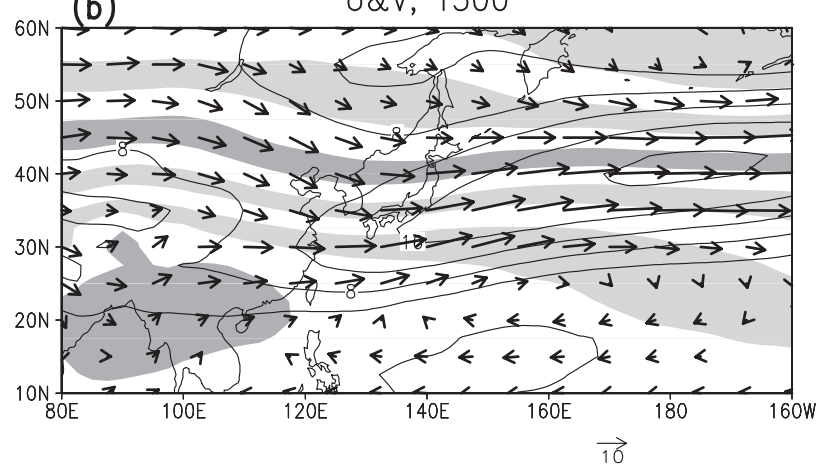

$(d)$

U\&V, T500

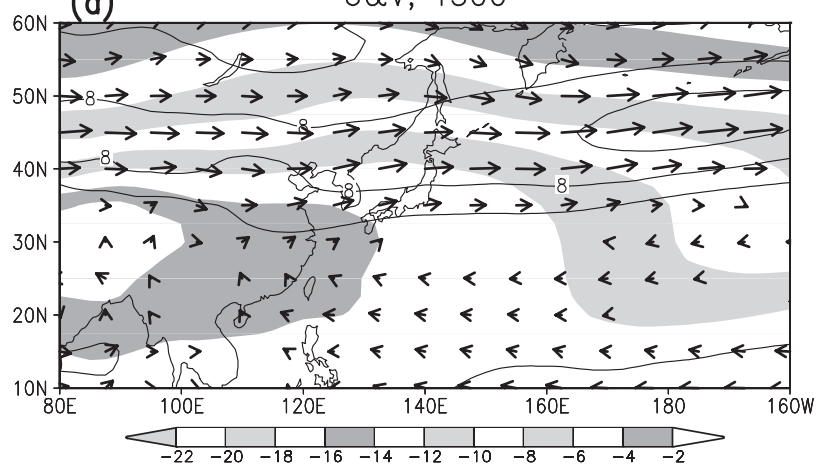

FIG. 7. Horizontal advection of temperature (black lines at every $0.2 \mathrm{~K} \mathrm{day}^{-1}$; negative contours are dashed and zero lines omitted) and upward vertical pressure velocity (Pa s${ }^{-1}$, shading) at $500 \mathrm{hPa}$ for (a) $17 \mathrm{May}-15 \mathrm{Jun}$ and (c) $16 \mathrm{Jul}-14 \mathrm{Aug}$. (b),(d) As in (a),(c) but for 500-hPa mean horizontal wind (arrows) and its speed (solid lines at every $4 \mathrm{~m} \mathrm{~s}^{-1}$ ) with 500 -hPa temperature $\left({ }^{\circ} \mathrm{C}\right.$, shading).

underlying SST and convective instability decrease, weakening the diabatic enhancement of upward motion.

The correlation of interannual variability of the ratio of convective to total precipitation with surface temperature (Fig. 8b) corroborates the influence of the latter on atmospheric convection. The correlation tends to be high along the meiyu-baiu rainband, supporting the importance of warm surface for convection.

\section{c. Cause of warm advection}

Temperature advection is dominated by that of the mean westerly jet and temperature field, while advection by transient eddies $\left(-\mathbf{v}^{\prime} \cdot \nabla T^{\prime}\right)$ is small (not shown). Figure $6 \mathrm{~b}$ shows the $500-\mathrm{hPa}$ mean wind velocity and temperature. The choice of $500 \mathrm{hPa}$ was meant to sidestep the difficulty with local convective feedback, as the wind response to diabatic heating of meiyu-baiu tends to be baroclinic and change signs at the midtroposphere (cf. appendix). The Tibetan Plateau anchors monsoon convection and hence a midtropospheric temperature maximum (Hahn and Manabe 1975; Li and Yanai 1996). Against this temperature field, the westerly wind causes warm advection from the eastern flank of the Plateau to the east of Japan. The northeast tilt of the westerly jet (Saito 1985) with a weak southerly component facilitates the warm advection along the meiyu-baiu rainband. North of the Tibetan Plateau, by contrast, the $500-\mathrm{hPa}$ jet runs southeastward, leading to cold advection over northern China. The cold advection corresponds to air parcels gliding down on isentropic surfaces, consistent with suppressed convection (Fig. 6a). This descent contributes to dry conditions on the north flank of the meiyu front.

Figures $7 \mathrm{~b}$,d show the 500-hPa wind and temperature one month before and after the meiyu-baiu season. In the early phase of meiyu-baiu (before mid-June), the $500-\mathrm{hPa}$ jet is diffluent around the Tibetan Plateau. The southern branch flows from the temperature maximum in the northern Bay of Bengal and southern China, advecting warm air toward the south of Japan (Figs. 7a,b). After mid-July, the jet is displaced north of the temperature maximum over the Tibetan Plateau and flows nearly in parallel to isotherms. As a result, the warm advection is weak over China and Japan (Figs. 7c,d). Figure 9 shows time-latitude sections of 500-hPa wind and temperature gradient in the upwind direction (left panels), together with temperature advection and upward velocity (right panels). In general, the wind blows down-temperature gradient along the jet axis, resulting in warm advection. The warm advection corresponds remarkably well with upward motion between $25^{\circ}$ and 

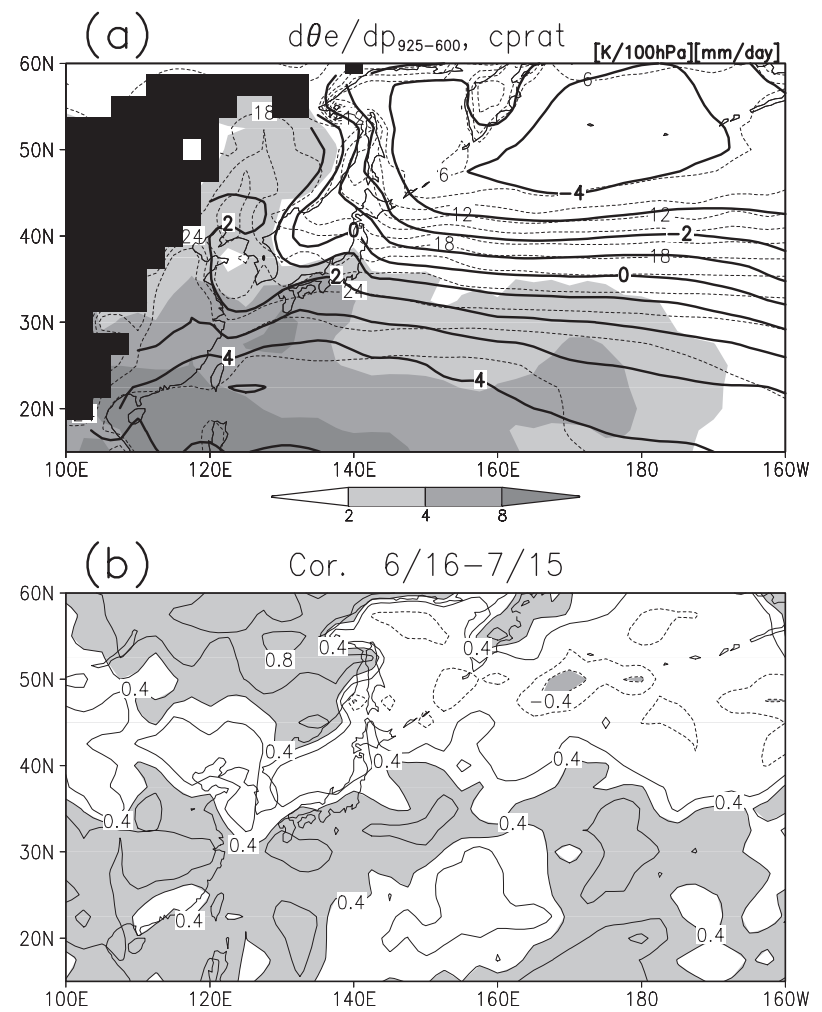

FIG. 8. (a) Meiyu-baiu (16 Jun-15 Jul) climatology of the vertical gradient of equivalent potential temperature between 925 and $600 \mathrm{hPa}$ [thick solid lines at every $1 \mathrm{~K}(100 \mathrm{hPa})^{-1}$; large values indicate unstable atmosphere], the surface temperature (thin dashed lines at every $2^{\circ} \mathrm{C}$ ), and the convective precipitation rate (gray shading, $\mathrm{mm} \mathrm{day}^{-1}$ ). (b) Correlation of interannual variations between surface temperature and the ratio of convective precipitation to total precipitation. Contour interval is 0.2 with negative contours dashed and zero lines omitted. Shaded where correlation is larger than 0.4. Correlation greater than 0.39 is significant for $95 \%$ confidence interval.

$40^{\circ} \mathrm{N}$, both of which exhibit a gradual northward migration in step with the jet. The induction of upward motion by warm advection explains the collocation of the meiyu-baiu rainband with the westerly jet, an empirical relation known from observations but unexplained so far. In late July, the westerly jet moves abruptly northward in association with the onset of a subtropical rainband to the south (Ueda et al. 1995, 2009). This abrupt shift in the jet weakens the warm advection, bringing an end to meiyu-baiu.

Our midtropospheric warm advection mechanism is distinct from the warm advection by low-level southerlies discussed in previous studies (e.g., Akiyama 1973; Ninomiya and Murakami 1987). Low-level winds are important for meiyu-baiu in moisture transport and convergence, while their thermal advection effect is weak especially over China. Moreover, the low-level circulation is strongly affected by diabatic heating (cf. appendix) and is part of the coupled problem of meiyu-baiu. The midtropospheric warm advection, by contrast, is determined not locally but by the planetary-scale monsoon system.

\section{Role of weather disturbances}

Slightly south of the meiyu-baiu front $\left(20^{\circ}-25^{\circ} \mathrm{N}\right)$, SST and convective instability are much higher on average than along the meiyu-baiu front over the northwestern Pacific (Fig. 8a). Yet convection is much more active in the latter region. The reason why convection is active despite weak mean instability may be due to disturbances generated and propagating in the waveguide of the westerly jet. In the meiyu-baiu rainband, synoptic-scale and various types of mesoscale disturbances are indeed frequently observed to propagate eastward (Ninomiya and Shibagaki 2007). Some of those mesoscale disturbances originate from so-called southwest vortices on the eastern flank of the Tibetan Plateau, which develop from the interaction of the southerly flow, orography, and convection (Tao and Ding 1981; Ding and Chan 2005; Yasunari and Miwa 2006). Sometimes the vertical coupling with mid-/upper-tropospheric disturbances can lead to strong (sub-) synoptic lows (Chang et al. 1998). These disturbances can cause substantial variability from the mean, creating periods with conditions favorable for convection in the meiyu-baiu rainband. This section explores the role of such disturbances as an environmental forcing in meiyu-baiu convection. In a synoptic view, frontogenesis and moisture supply by the large-scale low-level flow can reinforce the meiyu-baiu front and convection (Ninomiya 2000), but the low-level flow is subject to strong feedback from convective heating. Low moist stability in the meiyu-baiu frontal zone aids the development of disturbances through baroclinic instability (Ninomiya and Shibagaki 2003) or conditional symmetric instability (Bennetts and Hoskins 1979).

Figure 10a shows transient eddy activity measured as the standard deviation of the high-frequency meridional wind at $200 \mathrm{hPa}$. A high-pass filter with a cutoff period of 8 days is used. Upper-level disturbances are active along the jet stream and reach maximum intensity east of Japan, consistent with large near-surface baroclinicity (Fig. 1d) and low-level poleward eddy heat flux (Fig. 10c) over the Kuroshio-Oyashio Extension. Owing to large wind variability and a mean specific humidity gradient (Fig. 1e), fluctuations in low-level specific humidity are large between $30^{\circ}$ and $45^{\circ} \mathrm{N}$ (Fig. 10c). Variance of 500-hPa temperature exhibits large values in the mid- and high latitudes, decreasing equatorward steeply at $30^{\circ} \mathrm{N}$ (Fig. 10b). Eddy activity is weak south of $30^{\circ} \mathrm{N}$ by all these measures. Large fluctuations of temperature 

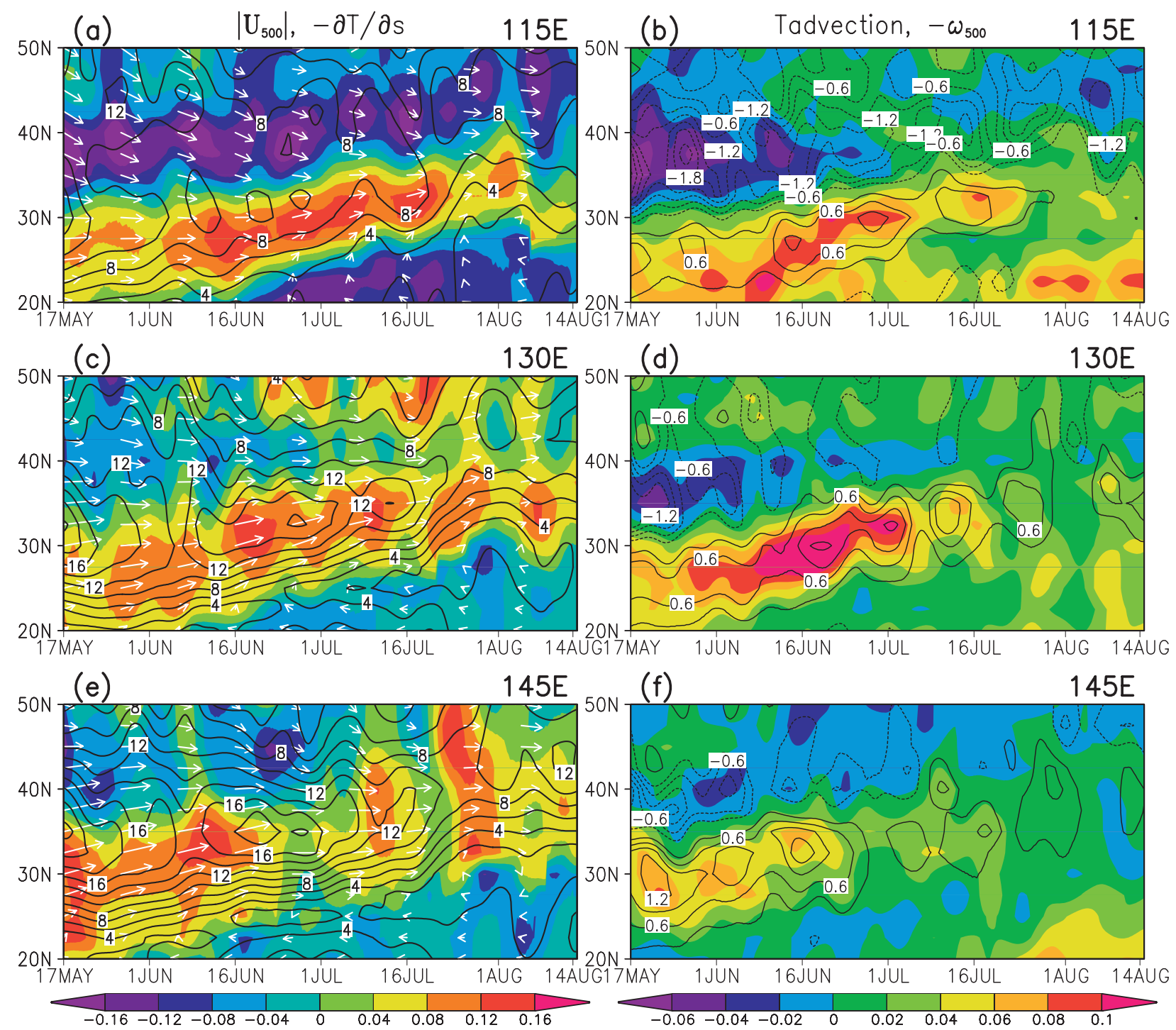

FIG. 9. (a),(c),(e) Time-latitude section of 500-hPa climatological-mean wind speed (contours at every $2 \mathrm{~m} \mathrm{~s}^{-1}$ ), its direction (white arrows), and temperature gradient in the upwind direction \{colors with scale at the bottom of (e); [K (100 km) $\left.\left.)^{-1}\right]\right\}$ at (a) $115^{\circ},(\mathrm{c}) 130^{\circ}$, (e) $145^{\circ}$ E. Shown from 17 May to 14 Aug. (b),(d),(f) As in (a),(c),(e) but for 500-hPa horizontal temperature advection (contours at every $0.3 \mathrm{~K} \mathrm{day}^{-1}$; negative contours are dashed and zero lines omitted) and 500-hPa upward vertical pressure velocity (colors, $\mathrm{Pa} \mathrm{s}{ }^{-1}$ ).

and moisture in the meiyu-baiu rainband render the atmosphere very unstable during certain periods of time, even though convective instability is weaker on average than to the south around $20^{\circ} \mathrm{N}$. Specifically, low-level convergence and upward motion that accompany cyclonic disturbances can trigger convection. Indeed, heavy rainfall events in meiyu-baiu are often associated with such organized dynamical disturbances.

Figure 11 shows the joint probability distribution of convective instability parameter $\left(\theta_{e 925}-\theta_{e 500}^{*}\right.$ in which $\theta_{e 500}^{*}$ is the saturation equivalent potential temperature at $500 \mathrm{hPa}$ ) and $500-\mathrm{hPa}$ horizontal temperature advection during the core meiyu-baiu season, calculated from 6-hourly JRA-25 data. If this instability parameter is positive, an air parcel at $925 \mathrm{hPa}$ would have upward buoyancy when lifted to the $500-\mathrm{hPa}$ level. The $500-\mathrm{hPa}$ temperature advection is used as a measure for the adiabatic forcing of vertical motion. Thus, convection is likely to occur if the atmospheric conditions move deeply into the upper-right quadrant in Fig. 11 where midtropospheric warm advection and convective instability are both large. Indeed, in the meiyu-baiu rainband (middle row), the spread in the joint probability distribution is large and the atmospheric conditions often stay in the upper-right quadrant where the probability of convective precipitation (color) is high, despite 


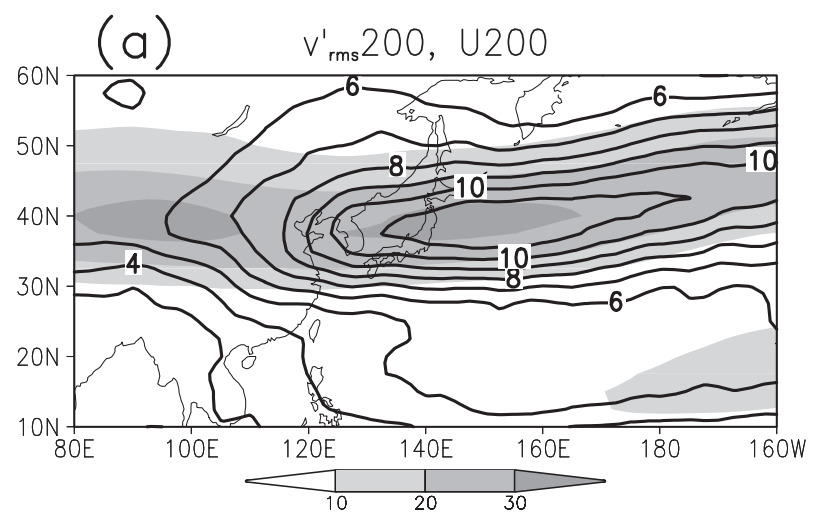

(b)
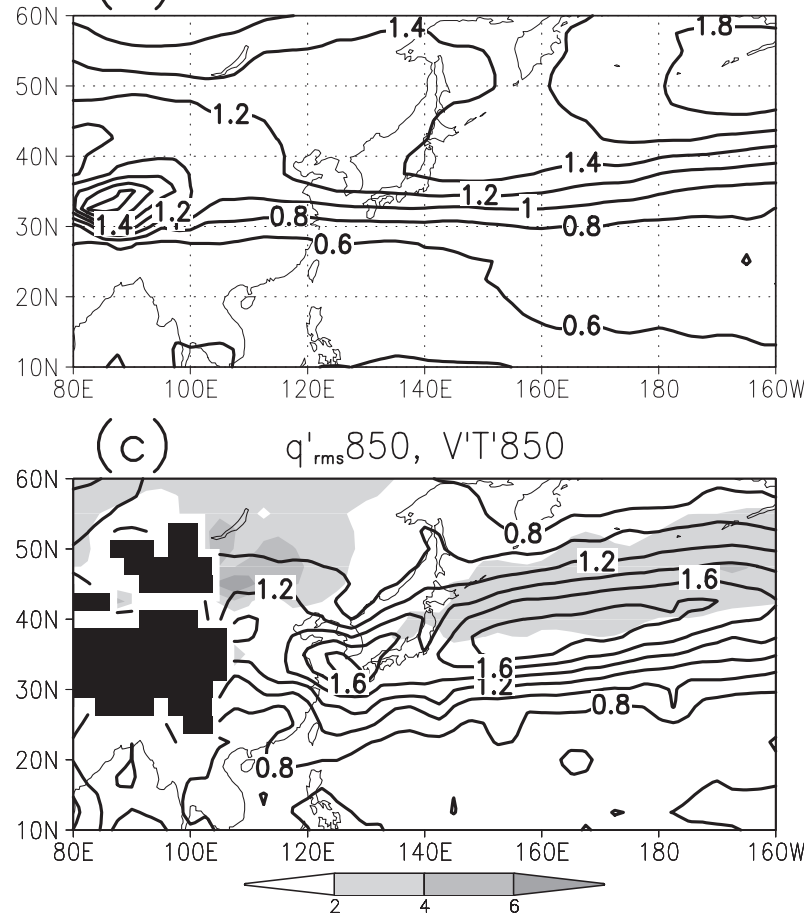

FIG. 10. Climatology of rms of high-pass filtered (a) $200-\mathrm{hPa}$ meridional wind (contours at every $1 \mathrm{~m} \mathrm{~s}^{-1}$ ), (b) $500-\mathrm{hPa}$ temperature (every $0.2 \mathrm{~K}$ ), and (c) $850-\mathrm{hPa}$ specific humidity (every $0.2 \times 10^{-3} \mathrm{~kg} \mathrm{~kg}^{-1}$ ) in meiyu-baiu season (16 Jun-15 Jul). In (a) $200-\mathrm{hPa}$ zonal wind speed is shown by shading $\left(\mathrm{m} \mathrm{s}^{-1}\right)$. In (c) 850-hPa poleward sensible heat flux by transient eddies is shown by shading $\left(\mathrm{K} \mathrm{m} \mathrm{s}^{-1}\right)$.

modest convective instability in the mean ( $\mathrm{X}$ mark in each panel). North of the baiu rainband and its extension, probability in the upper-right quadrant is low despite the large spread because of low SST and a stable atmosphere (Figs. $11 \mathrm{~b}, \mathrm{c}$ ). In northern China, at $40^{\circ} \mathrm{N}$, $115^{\circ} \mathrm{E}$ (Fig. 11a), there is modest probability of precipitation with sporadic convection, corresponding to the upper-right quadrant (cf. Fig. 8a). To the south of the meiyu-baiu rainband, the atmosphere is more unstable on average, but the spread of the probability distribution is much smaller with little joint probability for strong instability and warm advection (lower panels). All in all, conditions favorable for convection are satisfied more frequently in the meiyu-baiu rainband than to the south because of strong fluctuations associated with weather disturbances.

Figure 12a shows the probability distribution function (PDF) of the instability parameter $\left(\theta_{e 925}-\theta_{e 500}^{*}\right)$. The $\mathrm{PDF}$ at $22.5^{\circ} \mathrm{N}, 130^{\circ} \mathrm{E}$ is almost symmetrical with small standard deviation. In contrast, the PDF in the meiyubaiu rainband $\left(32.5^{\circ} \mathrm{N}, 130^{\circ} \mathrm{E}\right)$ exhibits negative skewness, decaying rapidly toward positive instability. This skewness is a clear signature of convective adjustment toward a near-neutral atmosphere. If convection were not allowed, the PDF at $32.5^{\circ} \mathrm{N}$ would be laterally symmetrical, so much higher instability values would appear. In reality, convection removes high instability, preventing the PDF from extending far into the right. In terms of the joint probability distribution, the major axis of the oval-shaped PDF in the baiu rainband and its extension (Figs. 11e,f) is noticeably tilted and skewed, with the most rapid drop of PDF in the upper-right quadrant. This supports the notion that warm advection and unstable vertical stratification are conducive to convection. By projecting the joint PDF in Fig. 11 on an upper-right tilting axis, PDFs for a combined index of moist instability and updraft induction, $\left(\theta_{e 925}-\theta_{e 500}^{*}\right)+$ $2 \times\left(-\mathbf{v}_{500} \cdot \nabla T_{500}\right)$, are obtained (Fig. 12b). The combined PDF exhibits negative skewness in the meiyu-baiu rainband $\left(32.5^{\circ} \mathrm{N}, 130^{\circ} \mathrm{E}\right)$ and is larger on the far right side than in the subtropics to the south $\left(22.5^{\circ} \mathrm{N}, 130^{\circ} \mathrm{E}\right)$, indicating an advantage of the meiyu-baiu region for convection.

Thus, mean convective instability is not a reliable indicator for convection, which occurs intermittently. Weather disturbances can cause the atmosphere to deviate strongly from the mean to convective states by advecting moisture and inducing upward motion through adiabatic dynamical processes. The results in this section reveal an additional role of the westerly jet in meiyu-baiu convection as the waveguide trapping transient disturbances.

\section{Connection between meiyu and baiu}

This section uses the LBM to explore the relationship between the meiyu over China and baiu over Japan. As discussed in the introduction, the planetary-scale land-sea contrast and elevated heating by the Tibetan Plateau drive the southerlies over eastern China and south of Japan, pushing precipitation northward (Xie and Saiki 1999). Indeed, many coarse-resolution AGCMs simulate meiyu-like summer rainfall over southeastern China to some extent. To investigate how meiyu 

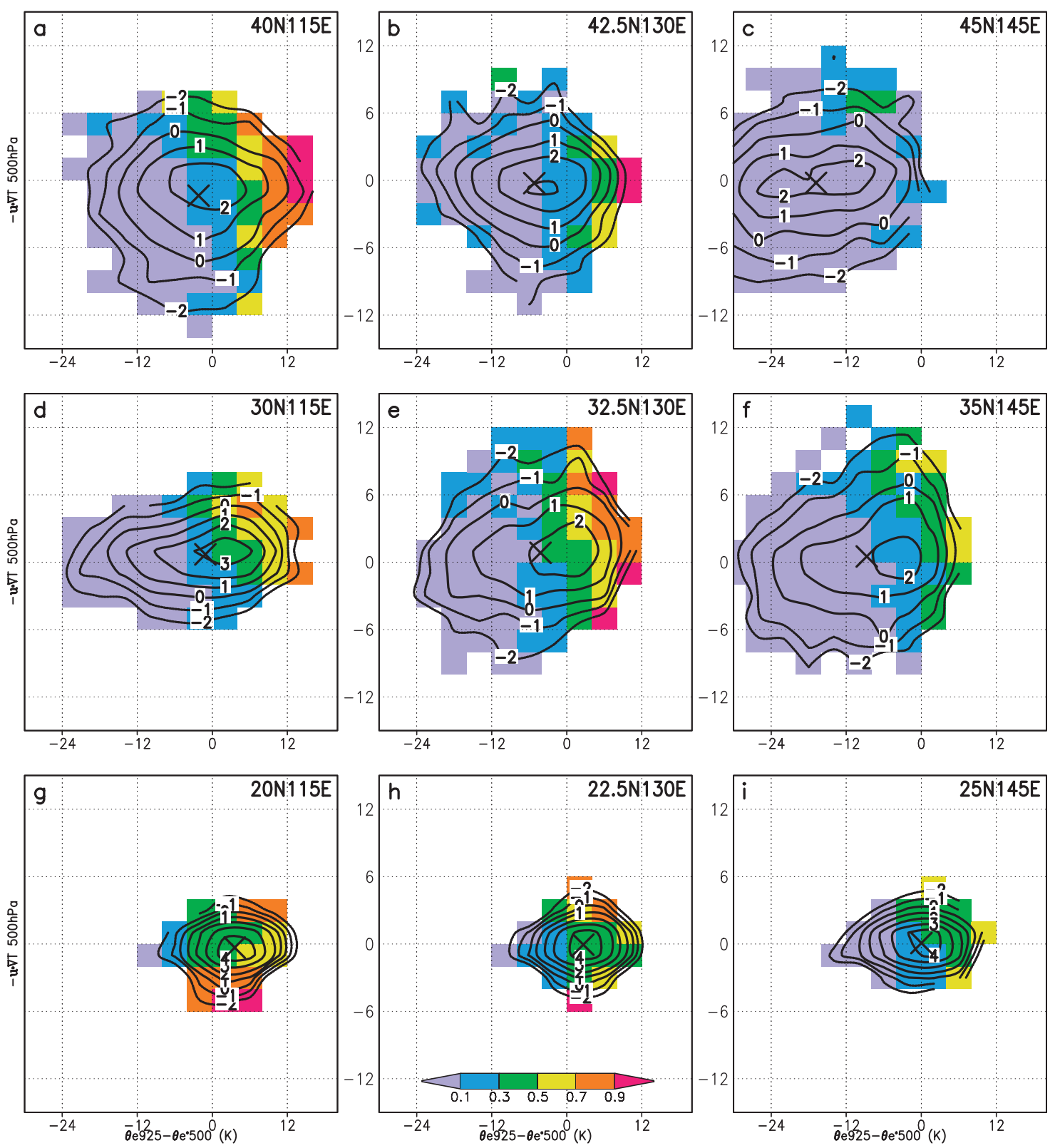

FIG. 11. Joint probability distribution (unit: $\log _{2}$ of percentage) of convective instability (abscissa, at $4-\mathrm{K}$ interval) and the $500-\mathrm{hPa}$ horizontal temperature advection (ordinate; at $2 \mathrm{~K} \mathrm{day}^{-1}$ interval) in the meiyu-baiu season. Here " $\mathrm{X}$ " marks the time mean. The instability parameter is defined as the difference between $925-\mathrm{hPa}$ equivalent potential temperature and 500 -hPa saturation equivalent potential temperature. Colors show the ratio of the time when convective precipitation exceeds $4 \mathrm{~mm} \mathrm{day}^{-1}$ to the whole period, under a given condition of the instability and advection [scale in (h)]. Geographical location of grid point is shown at the upper right corner, and (d)-(f) middle row corresponds to the meiyu-baiu frontal zone.

convection affects circulation downstream, we prescribe an idealized, oval-shaped heat source centered at $29^{\circ} \mathrm{N}$, $115^{\circ} \mathrm{E}$ to mimic meiyu heating. ${ }^{4}$ The vertical profile of

\footnotetext{
${ }^{4}$ The basic field is taken from the observed climatology that already contains the effect of meiyu-baiu heating. A run with a zonal-mean basic state yields qualitatively similar results.
}

the heating is based on the JRA-25 with a maximum of $5 \mathrm{~K} \mathrm{day}^{-1}$. The heating excites a surface trough extending east-northeastward (Fig. 13a) with southwesterly winds on the south side of the trough. The $500-\mathrm{hPa}$ ascent is strongest at the heat source but extends northeastward (Fig. 13b). Consistent with our observational diagnosis, the vertical velocity corresponds well to anomalous temperature advection downstream of the 


\section{(a)}

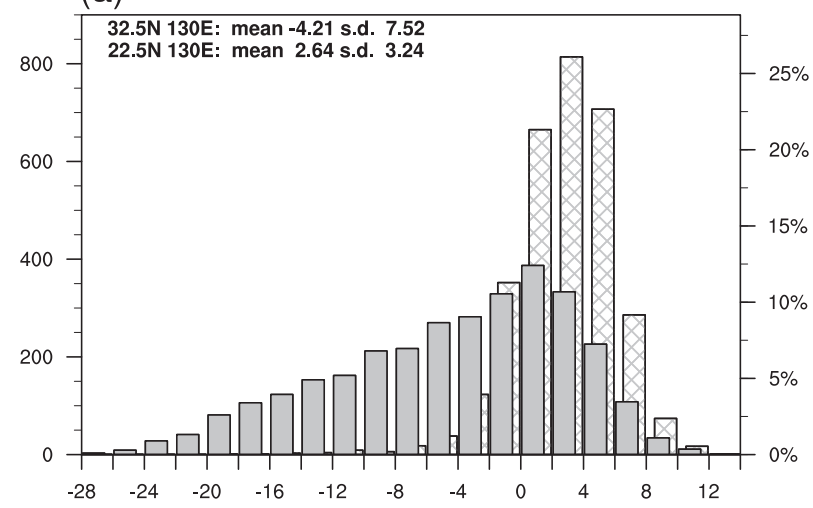

(b)

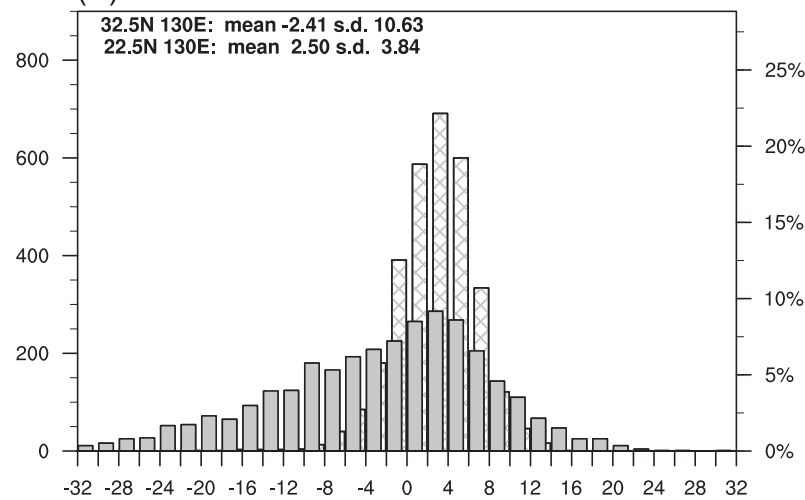

FIG. 12. (a) Histogram of the instability index, $\theta_{e 925}-\theta_{e 500}^{*}$ (abscissa, K), at $32.5^{\circ} \mathrm{N}, 130^{\circ} \mathrm{E}$ (shaded) and at $22.5^{\circ} \mathrm{N}, 130^{\circ} \mathrm{E}$ (hatched) in the core meiyu-baiu season (from 16 Jun to $15 \mathrm{Jul}$ ). The left and right ordinates denote the number of data in each bin and its percentage to the total number of data (3120) at each location, respectively. (b) As in (a) but for histogram of the sum of $\theta_{e 925}-\theta_{e 500}^{*}$ in the unit of $\mathrm{K}$ and $2 \times\left(-\mathbf{v}_{500} \cdot \nabla T_{500}\right)$ in $\mathrm{K} \mathrm{day}^{-1}$, so the abscissa has no physical unit but represents deviations in the upper-right direction in Figs. 11e,h.

heating $\left(-\overline{\mathbf{v}} \cdot \nabla T^{*}-\mathbf{v}^{*} \cdot \nabla \bar{T}\right.$; the asterisk denotes the LBM response; Fig. 13c).

As the wind response at $500 \mathrm{hPa}$ is weak (cf. Fig. A1), the warm advection here is mainly due to the westerly jet of the basic field acting on the temperature response to the prescribed heating (Fig. 13d). The warm advection and resultant upward motion extend along the observed meiyu-baiu rainband (Fig. 1a), suggesting that baiu may partly be induced by the upstream heating in meiyu. In other words, convection can be enhanced successively downstream in response to an upstream heating through warm advection by the westerly jet. To test this hypothesis, we place an oval-shaped heating over western Japan, assuming that it is triggered by the meiyu over China. Indeed, the prescribed baiu heating forces a surface trough and midtropospheric upward motion that extend eastward along the westerly jet (Figs. 13e,f).
These LBM results suggest a possible influence of meiyu convection on the baiu rainband and its eastward extension by adiabatic induction of upward motion. More generally, the meiyu-baiu rainband may be viewed in part as a result of successive downstream development of convection enabled by the westerly warm advection. By this mechanism, the forcing of meiyu-baiu may be traced all the way back to heating in the South Asian monsoon and by the Tibetan Plateau in particular.

Figure 14 shows the LBM response to the same heating as in Fig. 13, but with the August basic state. Compared to June, the August jet at $500 \mathrm{hPa}$ is displaced northward to $40^{\circ}-45^{\circ} \mathrm{N}$ and is weak (Fig. 14d). As a result, temperature advection by the mean wind $\left(-\overline{\mathbf{v}} \cdot \nabla T^{*}\right)$ is displaced northward and extends a much shorter distance from the heat source. The warm advection from the heating still induces upward motion, but the cool underlying SST is not conducive to convection. The warm land surface of Korea is an exception, allowing convection to be triggered by the remotely forced ascent (Fig. 14b), consistent with large rainfall observed over Korea even after mid-July, called "Changma" (Figs. 4c and 7c). Like upward motion, the surface SLP response is more localized zonally than in June, with the trough extending only over a short distance (Figs. 14a,e). The differences in the downstream response between Figs. 13 and 14 illustrate the importance of the basic-state wind. Thus the westerly jet acts as a conduit for downstream influence via warm advection and induced upward motion. To the west of the prescribed heating, subsidence forms with warm tropospheric temperature and a high SLP response, indicative of baroclinic Rossby waves.

\section{Summary and discussion}

We have examined large-scale, climatological characteristics of meiyu-baiu using the JRA-25 reanalysis. In the SLP field, the meiyu-baiu rainband appears as a weak trough around Japan (Fig. 1). Meiyu over China features sharp moisture gradients but weak temperature gradients. In baiu over Japan, both moisture and temperature gradients are large. Farther to the east, the oceanic frontal zone maintains sharp gradients in both temperature and humidity, where the rainband is similar to a storm track along a polar front because low SST suppresses convection while synoptic-scale eddies develop over the sharp temperature gradient (Figs. 8 and 10). The westerly jet exhibits a distinct northward tilt with height, and the meiyu-baiu rainband is collocated with the midtropospheric westerly axis (Fig. 2). These characteristic features of meiyu-baiu have been discussed in previous studies (e.g., Akiyama 

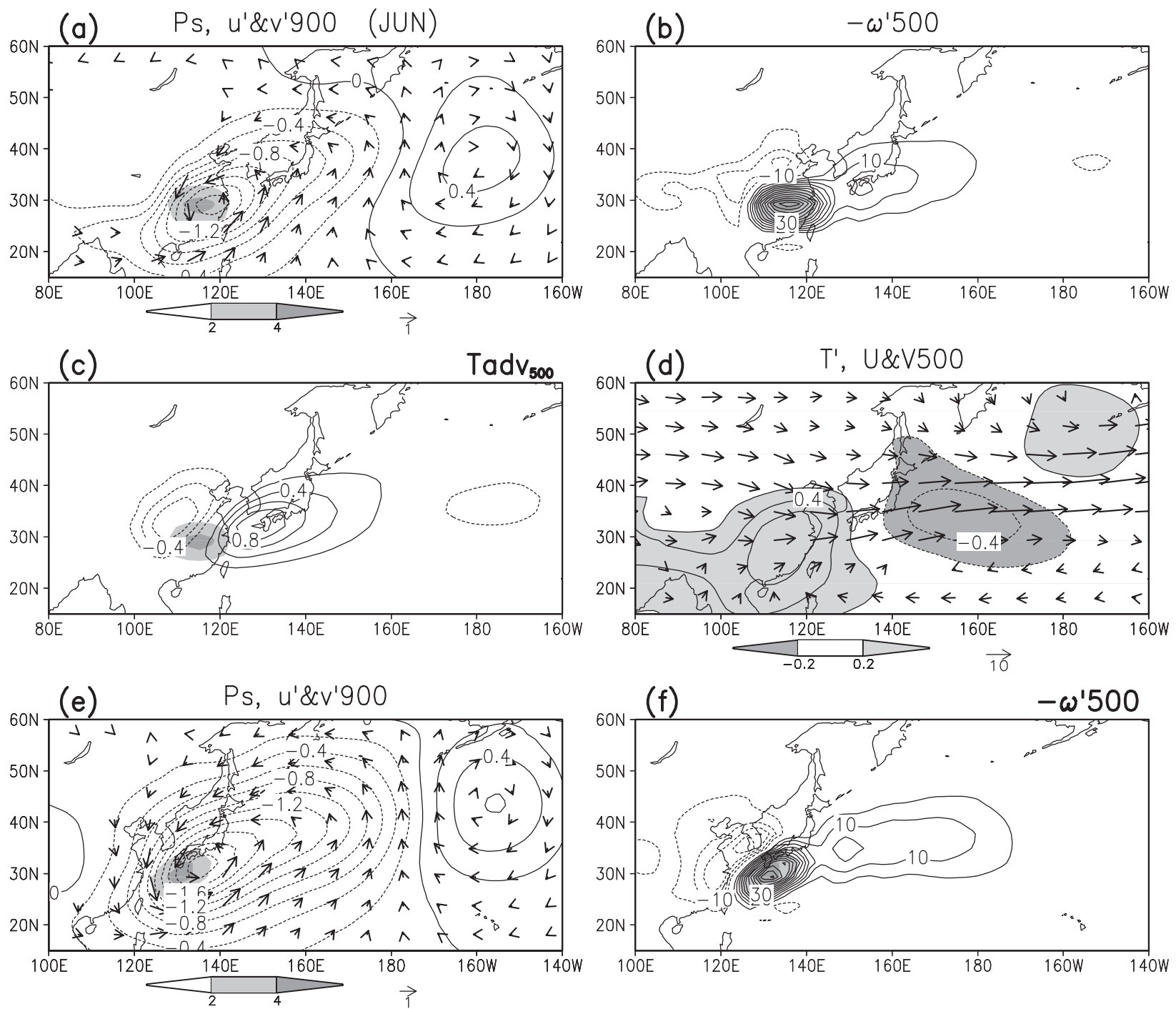

FIG. 13. (a)-(d) LBM response to idealized heating centered at $29^{\circ} \mathrm{N}, 115^{\circ} \mathrm{E}$. (a) Surface pressure (contours at every $0.2 \mathrm{hPa}$ ) and 900 -hPa wind (arrows, $\mathrm{m} \mathrm{s}^{-1}$ ). (b) Upward vertical pressure velocity (unit: $10^{-3} \mathrm{~Pa} \mathrm{~s}^{-1}$; contours at every 5). (c) Horizontal temperature advection at $500 \mathrm{hPa}$ (contours at every $0.2 \mathrm{~K} \mathrm{day}^{-1}$ ). (d) Horizontal wind of the June basic state (arrows, $\mathrm{m} \mathrm{s}^{-1}$ ) and temperature response (contours at every $0.2 \mathrm{~K}$ with shading) at $500 \mathrm{hPa}$. In (b)-(d) zero lines are omitted. Prescribed heating rate is shown in (a)-(c) by shading [scale at bottom of (a)]. (e),(f) As in (a),(b) but for idealized heating centered at $30^{\circ} \mathrm{N}, 131^{\circ} \mathrm{E}$.

1973; Ninomiya and Murakami 1987) and are generally confirmed in the reanalysis.

\section{a. Environmental forcing by the westerly jet}

Of the above features, some are forced by diabatic heating in meiyu-baiu. Our results show that the northward tilt of the westerly axis is an example. Aided with LBM, our results identify low-level southerlies over the Far East and the midtropospheric westerly jet as external environmental features important for meiyu-baiu. The 500-hPa horizontal winds are little affected by meiyubaiu heating (cf. appendix). The present study shows a remarkable correspondence in the midtroposphere between horizontal warm advection by the westerlies and upward motion along the meiyu-baiu rainband from late May through August (Figs. 6, 7, and 9). The thermodynamic balance suggests that the former causes the latter and the following hypothesis is proposed. Riding on the westerlies, warm air from the eastern flank of the Tibetan Plateau gradually rises on the sloping isentropic surface. To the extent that the warm advection is determined by the planetary-scale environment, it is a remote forcing that anchors the meiyu-baiu rainband. The advection of warm air from the eastern flank of the Tibetan Plateau triggers convection over southeastern China by inducing adiabatic ascent along the 

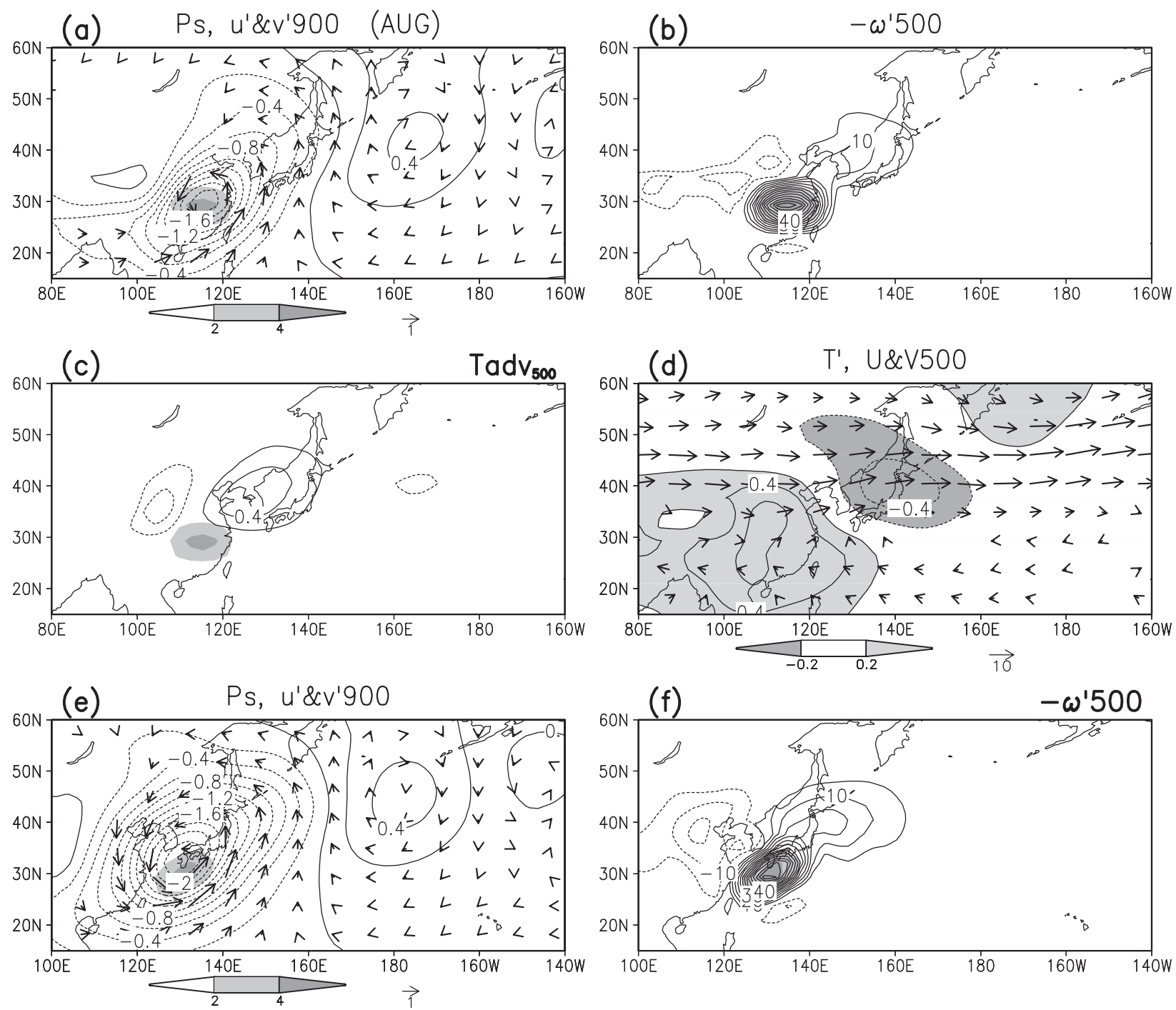

FIG. 14. As in Fig. 13 but for LBM experiment with the August basic state.

westerly jet. In addition, our LBM results suggest a successive downstream development of convection: meiyu convection increases warm advection and promotes convection downstream in the baiu rainband over and east of Japan (Figs. 13 and 14).

In the subtropics, the sum of horizontal temperature advection and diabatic heating roughly balances vertical advection (Rodwell and Hoskins 1996). The upward motion induced by warm advection promotes convection and is enhanced by the resultant condensational heating. This diabatic enhancement of upward motion varies along the meiyu-baiu rainband from China to the North Pacific east of Japan, consistent with convective instability of the lower troposphere. The upward motion in meiyu-baiu over China and western Japan is much greater than what the horizontal warm advection in- duces, consistent with high surface humidity and convective instability. The ascent in the baiu extension east of Japan, on the other hand, is close to what is implied by the horizontal warm advection, consistent with a stable atmosphere over cool SST (Fig. 8). One may argue that the small ratio of the adiabatically induced ascent over China and western Japan indicates that it is less significant than convection heating for the meiyu-baiu formation. However, the convection heating is not an environmental forcing but depends on the meiyubaiu system itself. The present study suggests that the remote forcing represented by the midtropospheric warm advection determines the location and timing of the meiyu-baiu formation, while convection controls the intensity of rainfall and upward motion in meiyubaiu. 


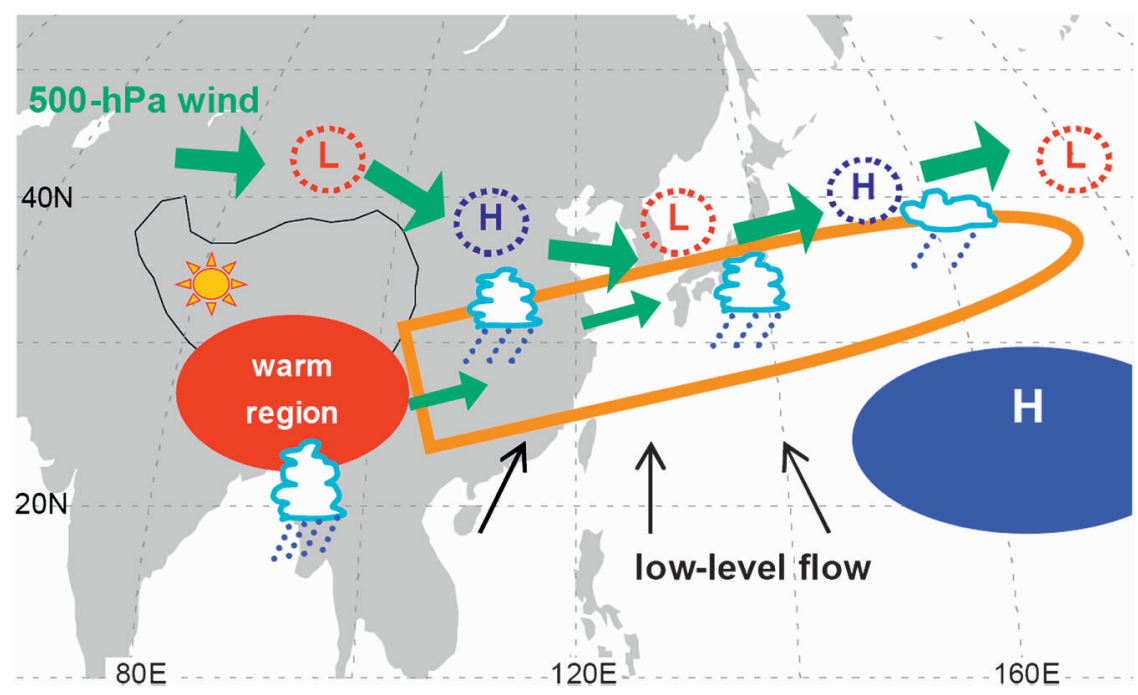

FIG. 15. Schematic diagram describing factors that bring meiyu-baiu in early summer East Asia. Midtropospheric winds (green arrows) advect warm air from the warm region over the south flank of the Tibetan Plateau (red oval; thin black line is the 3000-m contour of topography) associated with the heated surface of the Plateau and monsoon convection to the south. The warm advection over central China and Japan (orange) induces ascending motion along the jet stream. The ascent favors convection (drawing of clouds in orange figure) in the presence of convective instability sustained by low-level southerly moisture transport (black arrows) between a heat low over the continent and an oceanic high over the North Pacific (light blue oval with "H"). The jet stream (thick green arrows) steers transient weather disturbances from midlatitudes (blue and red dotted circles with " $H$ " and "L") eastward, increasing probability of intense ascent and instability. The location of atmospheric components in this diagram varies.

Surface evaporation under the rainband varies greatly between land and ocean. North of the NPSH axis, southerly/southwesterly winds prevail and blow "down SST gradient." The warm and moist advection suppresses surface evaporation and often causes fog (surface condensation) over the Yellow Sea (Zhang et al. 2009) and Kuroshio-Oyashio Extension (Tokinaga et al. 2009). Tanimoto et al. (2009) suggest that the suppressed surface evaporation by the southerlies is a negative feedback for the baiu rainband. Surface latent heat flux is about $150 \mathrm{~W} \mathrm{~m}^{-2}$ under meiyu in China but only 50 or less in the Yellow-East China Sea and under the baiu extension east of Japan. These variations in surface evaporation may contribute to stronger convective instability over China.

Our analysis reveals another mechanism for the westerly jet to induce meiyu-baiu convection. The mean stratification is not a reliable predictor for convection over the northwestern Pacific warm water pool. The westerly jet is a waveguide for energetic weather disturbances, which cause large excursions from the mean and create periods of favorable conditions for strong convection (Fig. 10). Indeed, the atmospheric state with strong convective instability and upward motion occurs more frequently in the meiyu-baiu rainband than in the subtropics to the south, despite higher SST in the latter region. The convective instability PDF is strongly skewed with a sharp cutoff at high values, indicative of convection that removes high instability (Figs. 11 and 12). Thus the collocation of the midtropospheric westerly jet and the meiyu-baiu rainband is not a mere coincidence but reflects the dynamics of the rainband. The jet anchors the rainband by warm advection and by causing large excursions into highly convective states through the weather disturbances that it steers.

\section{b. Conceptual model}

The results of the present study lead us to propose the following conceptual model for meiyu-baiu, as summarized schematically in Fig. 15. In June, the temperature maximum in the midtroposphere advances inland to southern Tibet as part of the developing South Asian monsoon (e.g., Li and Yanai 1996). The midtropospheric westerlies advect warm air from the eastern flank of the Tibetan Plateau along the jet axis, inducing ascending motion that triggers convection to form the meiyu-baiu rainband. Weather disturbances steered by the jet further promote convection by intensifying lowlevel moisture advection with transient upward motion. 
At the surface, the SLP trough, horizontal wind shear, southward-displaced jet, and moisture front form in response to convective heating in meiyu-baiu (cf. appendix). In late July, the jet stream migrates northward, but the midtropospheric temperature maximum cannot follow as it is anchored by the Tibetan Plateau (Hahn and Manabe 1975), weakening the warm advection to end meiyu-baiu. Our conceptual model is dynamical and explicitly identifies the westerly jet as an environmental forcing of meiyu-baiu convection, while their association is merely noted in the literature without presenting clear causality. Other external environmental factors include the low-level southerlies in the Far East and SST. The southerlies transport moisture to feed convection over southern China as early as in April (cf. Ding and Chan 2005), while the SST warming in the northwestern Pacific helps set mid-June to mid-July as the core period for meiyu-baiu. The Tibetan Plateau makes important contributions to meiyu-baiu formation by 1) strengthening the surface southerly flow over China, 2) anchoring the westerly warm advection in the midtroposphere, and 3) initiating southwest vortices on the eastern flank. Indeed, in atmospheric and coupled GCMs, a removal of mountains substantially weakens summer rainfall over subtropical East Asia (e.g., Kitoh 2004; Okajima and Xie 2007).

The decay of meiyu-baiu convection in late July is associated with the abrupt onset of convective activity to the south in the subtropical northwestern Pacific along $20^{\circ} \mathrm{N}$ (Ueda et al. 1995). Our study indicates that energetic weather disturbances help the meiyu-baiu rainband win the competition for convection against the warmer subtropical Pacific. What reverses the fortune to favor the subtropical Pacific for convection in late July remains unclear (Ueda et al. 2009). The meridional dipole of the PJ pattern (Nitta 1987) is involved in the shift, displacing the westerly jet northward to weaken the warm advection from Tibet and disfavor convection along the jet. A similar pattern appears as the dominant mode in an empirical orthogonal function (EOF) analysis of interannual variability in meiyu-baiu rainfall (not shown). This mode of meiyu-baiu variability is significantly correlated with $\mathrm{El}$ Niño in the previous winter (Huang et al. 2004), a delay likely due to the effect of Indian Ocean SST anomalies (Yang et al. 2007; Xie et al. 2009). Research is underway to investigate meiyu-baiu variability in light of the dynamics presented here. Indeed, changes in the midtropospheric westerly jet associated with the EOF pattern are consistent with its role as environmental forcing of meiyu-baiu convection, with increased rainfall when the jet is anomalously strong. Our conceptual model can also be tested in other subtropical convergence zones in the South Pacific and South At- lantic, where the westerly jet is considered to be essential for active rainbands (Kodama 1993).

Acknowledgments. We wish to thank H. Nakamura for his helpful comments, B. Hoskins for helpful discussion, anonymous reviewers for comments that led us to clarify distinct roles of environmental forcing and internal feedback, and M. Watanabe for permitting the use of the LBM. This work is supported by the Japan Agency for Marine-Earth Science and Technology, NASA, NSF, and NOAA.

\section{APPENDIX}

\section{Response to Meiyu-Baiu Heating}

Low-level circulation is important to supply moisture into the meiyu-baiu rainband. Here we use the LBM and show that the response to condensational heating in the rainband accounts for many observed characteristics of the low-level circulation. Figure A1 shows the LBM response to heating along the meiyu-baiu rainband and its extension $\left(25^{\circ}-50^{\circ} \mathrm{N}, 100^{\circ} \mathrm{E}-160^{\circ} \mathrm{W}\right)$ in June based on JRA-25. We use the zonally varying June climatology as the basic state. When the zonal-mean basic state is used, the surface low is shifted westward because of the weaker zonal-mean low-level westerlies.

The heating forces a baroclinic Rossby wave with subsidence propagating westward. More conspicuously, it induces an elongated surface low with upward motion extending downstream toward the northeast (Fig. A1a). This suggests that the observed surface trough (Fig. 1b) is a response to meiyu-baiu heating. Indeed, if the LBM response is subtracted from the June climatology, the SLP trough and the westward protrusion of the NPSH axis around $25^{\circ} \mathrm{N}$-characteristic features of meiyubaiu-become unrecognizable (not shown). The response also explains the horizontal wind shear observed along the meiyu-baiu front and the strong southwesterlies to the south in particular. The wind shear in turn helps maintain the sharp gradients of moisture and equivalent potential temperature; that is, the meiyu-baiu front (Fig. 1), in concert with mean descending motions over northern China (Fig. 6a).

Figures A1b-d show meridional sections of the response at $132^{\circ} \mathrm{E}$. The response has a baroclinic structure (Fig. A1b) and reinforces the westerlies on the north side of the heating in the upper troposphere and on the south side in the lower troposphere (Fig. A1c) through Coriolis acceleration of the meridional ageostrophic circulation (Fig. A1d). This zonal wind response explains the observed northward tilt of the westerly jet (Fig. 2), while the barotropic component of 
(a) $\quad P s^{\prime}, u^{\prime} \& v^{\prime} 900$
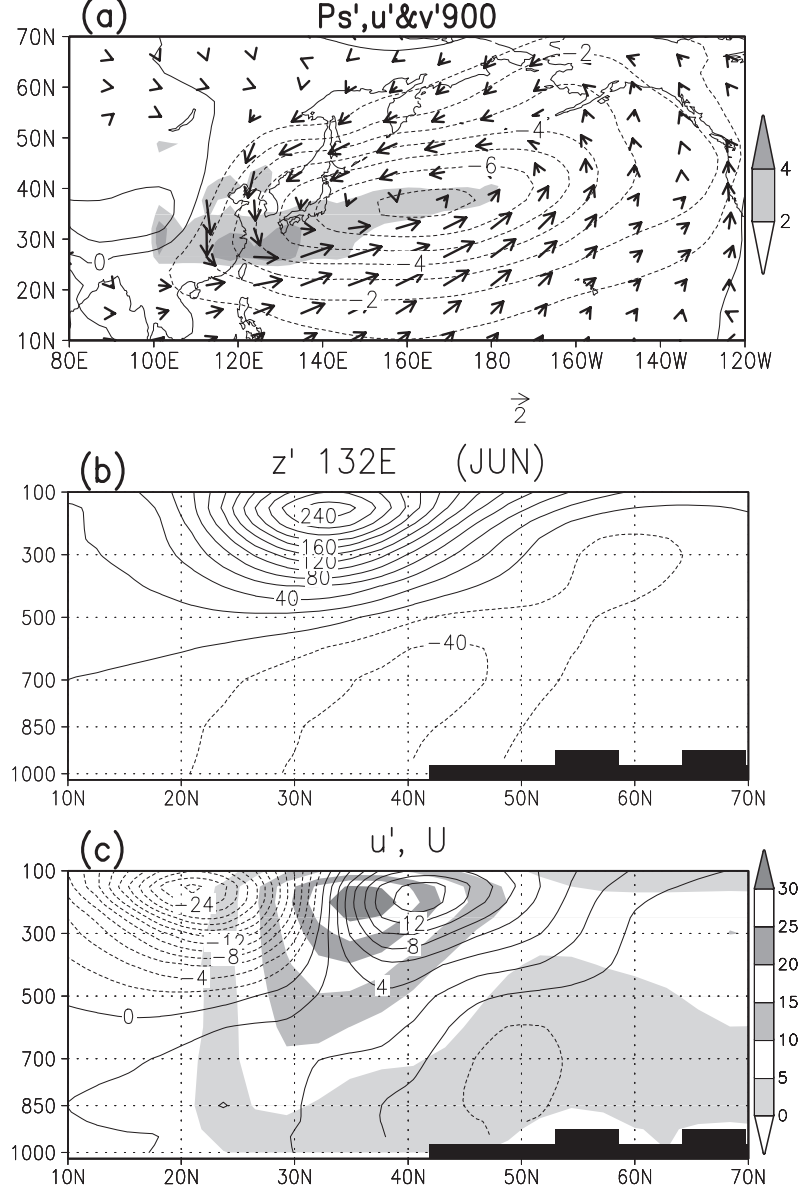

(d) $\quad v_{0}^{\prime} \&-\omega^{\prime} \times 20, \quad T^{\prime}$

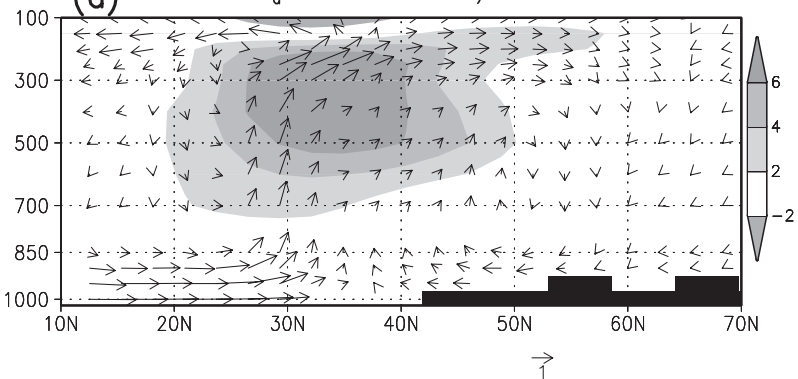

FIG. A1. LBM response to June heating of JRA-25 prescribed in the domain $\left(25^{\circ}-50^{\circ} \mathrm{N}, 100^{\circ} \mathrm{E}-160^{\circ} \mathrm{W}\right)$. (a) Surface pressure (contours at every $1 \mathrm{hPa}$ ), 900-hPa wind (arrows) and the prescribed heating at the 0.45 sigma level (shading, $\mathrm{K}_{\text {day }}{ }^{-1}$ ). Meridional sections at $132^{\circ} \mathrm{E}$ : (b) geopotential height (contours at every $20 \mathrm{~m}$ ); (c) zonal wind velocity (contours at every $2 \mathrm{~m} \mathrm{~s}^{-1}$ ) overlaid on the basic-state zonal wind velocity (shading, $\mathrm{m} \mathrm{s}^{-1}$ ); (d) temperature (shading in $\mathrm{K}$ ) with meridional and vertical components of ageostrophic wind (arrows in $\mathrm{m} \mathrm{s}^{-1}$ and $\mathrm{Pa} \mathrm{s}^{-1}$, respectively; vertical component is multiplied by 20 ).

the observed jet is considered as an environment for the meiyu-baiu rainband rather than a response to it. Our results clearly show the effects of the meiyu-baiu heating, extending a previous study based on a 2D quasi- geostrophic calculation (Yamazaki and Chen 1993). The southwesterly moist flow supplies moisture for meiyubaiu precipitation, on the one hand, and much of the low-level circulation is forced by condensational heating in the rainband, on the other. Thus, the low-level circulation and meiyu-baiu convection form a pair of interactive phenomena. The LBM fails to reproduce the low-level southerlies on the eastern seaboard of China, indicating the importance of diabatic heating outside the meiyu-baiu rainband, such as differential heating between land and ocean (e.g., Xie and Saiki 1999). Models have shown that heat sources in South Asia and the tropical western Pacific force ascending motion that extends northeastward to East Asia (Ose 1998; Liu et al. 2007).

\section{REFERENCES}

Akiyama, T., 1973: The large-scale aspects of the characteristic features of the Baiu front. Pap. Meteor. Geophys., 24 (2), 157-188.

Bennetts, D. A., and B. J. Hoskins, 1979: Conditional symmetric instability-a possible explanation for frontal rainbands. Quart. J. Roy. Meteor. Soc., 105, 945-962.

Bolton, D., 1980: The computation of equivalent potential temperature. Mon. Wea. Rev., 108, 1046-1053.

Chang, C.-P. Ed., 2004: East Asian Monsoon. World Scientific, $564 \mathrm{pp}$.

- S. C. Hou, H. C. Kuo, and T.-J. G. Chen, 1998: The development of an intense East Asian summer monsoon disturbance with strong vertical coupling. Mon. Wea. Rev., 126, 2692-2712.

Chen, T.-J. G., and C.-P. Chang, 1980: The structure and vorticity budget of an early summer monsoon trough (Mei-Yu) over southeastern China and Japan. Mon. Wea. Rev., 108, 942-953.

, C.-C. Wang, and S. C.-S. Liu, 2003: Potential vorticity diagnostics of a Mei-Yu front case. Mon. Wea. Rev., 131, 2680-2696.

Cho, H.-R., and T.-J. G. Chen, 1995: Mei-Yu frontogenesis. J. Atmos. Sci., 52, 2109-2120.

Chou, C., J. D. Neelin, and H. Su, 2001: Ocean-atmosphere-land feedbacks in an idealized monsoon. Quart. J. Roy. Meteor. Soc., 127, 1869-1891.

Ding, Y., and J. C. L. Chan, 2005: The East Asian summer monsoon: an overview. Meteor. Atmos. Phys., 89, 117-142.

Enomoto, T., B. J. Hoskins, and Y. Matsuda, 2003: The formation mechanism of the Bonin high in August. Quart. J. Roy. Meteor Soc., 129, 157-178.

Gritsun, A., and G. Branstator, 2007: Climate response using a threedimensional operator based on the fluctuation-dissipation theorem. J. Atmos. Sci., 64, 2558-2575.

Hahn, D. G., and S. Manabe, 1975: The role of mountains in the South Asian monsoon circulation. J. Atmos. Sci., 32, 1515-1541.

Huang, R., W. Chen, B. Yang, and R. Zhang, 2004: Recent advances in studies of the interaction between the East Asian winter and summer monsoons and ENSO cycle. Adv. Atmos. Sci., 21, 407-424.

Huffman, G. J., and Coauthors, 1997: The Global Precipitation Climatology Project (GPCP) combined precipitation dataset. Bull. Amer. Meteor. Soc., 78, 5-20. 
Jin, F.-F., L.-L. Pan, and M. Watanabe, 2006: Dynamics of synoptic eddy and low-frequency flow interaction. Part I: A linear closure. J. Atmos. Sci., 63, 1677-1694.

Kato, K., 1989: Seasonal transition of the lower-level circulation systems around the Baiu Front in China in 1979 and its relation to the Northern Summer Monsoon. J. Meteor. Soc. Japan, 67, 249-265.

Kawamura, R., and T. Murakami, 1998: Baiu near Japan and its relation to summer monsoons over Southeast Asia and the western North Pacific. J. Meteor. Soc. Japan, 76, 619-639.

Kawatani, Y., and M. Takahashi, 2003: Simulation of the Baiu front in a high resolution AGCM. J. Meteor. Soc. Japan, 81, $113-126$.

Kitoh, A., 2004: Effects of mountain uplift on East Asian summer climate investigated by a coupled atmosphere-ocean GCM J. Climate, 17, 783-802.

Kodama, Y.-M., 1992: Large-scale common features of subtropical precipitation zones (the Baiu frontal zone, the SPCZ, and the SACZ). Part I: Characteristics of subtropical frontal zones. J. Meteor. Soc. Japan, 70, 813-836.

_ 1 1993: Large-scale common features of subtropical convergence zones (the Baiu frontal zone, the SPCZ, and the SACZ). Part II: Conditions of the circulations for generating the STCZs. J. Meteor. Soc. Japan, 71, 581-610.

Kosaka, Y., and H. Nakamura, 2006: Structure and dynamics of the summertime Pacific-Japan teleconnection pattern. Quart. J. Roy. Meteor. Soc., 132, 2009-2030.

Lau, N.-C., and J. J. Ploshay, 2009: Simulation of synoptic- and subsynoptic-scale phenomena associated with the East Asian summer monsoon using a high-resolution GCM. Mon. Wea. Rev., 137, 137-160.

Li, C., and M. Yanai, 1996: The onset and interannual variability of the Asian summer monsoon in relation to land-sea thermal contrast. J. Climate, 9, 358-375.

Liu, Y., B. J. Hoskins, and M. Blackburn, 2007: Impact of Tibetan orography and heating on the summer flow over Asia. J. Meteor. Soc. Japan, 85B, 1-19.

Lu, R., and B. Dong, 2001: Westward extension of North Pacific subtropical high in summer. J. Meteor. Soc. Japan, 79, 1229 1241.

Matsumoto, S., K. Ninomiya, and S. Yoshizumi, 1971: Characteristic features of "Baiu" front associated with heavy rainfall J. Meteor. Soc. Japan, 49, 267-281.

Murakami, T., 1958: The sudden change of upper westerlies near the Tibetan Plateau at the beginning of summer season. J. Meteor. Soc. Japan, 36, 239-247.

_ continent and western Pacific. J. Meteor. Soc. Japan, 72, 719-745.

Nakamura, H., 1992: Midwinter suppression of baroclinic wave activity in the Pacific. J. Atmos. Sci., 49, 1629-1642.

_ , and A. S. Kazmin, 2003: Decadal changes in the North Pacific oceanic frontal zones as revealed in ship and satellite observations. J. Geophys. Res., 108, 3078, doi:10.1029/1999JC000085.

_ , and T. Fukamachi, 2004: Evolution and dynamics of summertime blocking over the Far East and the associated surface Okhotsk high. Quart. J. Roy. Meteor. Soc., 130, 1213-1233.

Ninomiya, K., 1980: Enhancement of Asian subtropical front due to thermodynamic effect of cumulus convections. J. Meteor. Soc. Japan, 58, 1-15.

_ 1984: Characteristics of Baiu front as a predominant subtropical front in the summer Northern Hemisphere. J. Meteor. Soc. Japan, 62, 880-894.
2000: Large- and meso- $\alpha$-scale characteristics of Meiyu/Baiu front associated with intense rainfalls in 1-10 July 1991. J. Meteor. Soc. Japan, 78, 141-157.

— during Baiu period of 1979. J. Meteor. Soc. Japan, 64, 409-429.

— , and T. Murakami, 1987: The early summer rainy season (Baiu) over Japan. Monsoon Meteorology, C.-P. Chang, and T. N. Krishnamurti, Eds., Oxford University Press, 93-121.

- , and Y. Shibagaki, 2003: Cloud system families in the MeiyuBaiu front observed during 1-10 July 1991. J. Meteor. Soc. Japan, 81, 193-209.

— , and — 2007: Multi-scale features of the Meiyu-Baiu front and associated precipitation systems. J. Meteor. Soc. Japan, 85B, 103-122.

— , T. Enomoto, T. Nishimura, T. Suzuki, and S. Matsumura, 2003: Synoptic- and meso- $\alpha$-scale variations of the Baiu front simulated in an AGCM. J. Meteor. Soc. Japan, 81, 1387-1405.

Nitta, T., 1987: Convective activity in the tropical western Pacific and their impact on the Northern Hemisphere summer circulation. J. Meteor. Soc. Japan, 65, 373-390.

Onogi, K., and Coauthors, 2007: The JRA-25 reanalysis. J. Meteor. Soc. Japan, 85, 369-432.

Okajima, H., and S.-P. Xie, 2007: Orographic effects on the northwestern Pacific monsoon: Role of air-sea interaction. Geophys. Res. Lett., 34, L21708, doi:10.1029/2007GL032206.

Ose, T., 1998: Seasonal change of Asian summer monsoon circulation and its heat source. J. Meteor. Soc. Japan, 76, 1045-1063.

Rodwell, M. J., and B. J. Hoskins, 1996: Monsoons and the dynamics of deserts. Quart. J. Roy. Meteor. Soc., 122, 1385-1404. , and _ 2001: Subtropical anticyclones and summer monsoons. J. Climate, 14, 3192-3211.

Saito, N., 1966: A preliminary study of the summer monsoon of southern and eastern Asia. J. Meteor. Soc. Japan, 44, 44-59.

, 1985: Quasi-stationary waves in mid-latitudes and the Baiu in Japan. J. Meteor. Soc. Japan, 63, 983-995.

Tanimoto, Y., S.-P. Xie, K. Kai, H. Okajima, H. Tokinaga, T. Murayama, M. Nonaka, and H. Nakamura, 2009: Observations of marine atmospheric boundary layer transitions across the summer Kuroshio Extension. J. Climate, 22, 1360-1374.

Tao, S., and Y. Ding, 1981: Observational evidence of the influence of the Qinghai-Xizang (Tibet) Plateau on the occurrence of heavy rain and severe convective storms in China. Bull. Amer. Meteor. Soc., 62, 23-30.

- , and L. Chen, 1987: A review of recent research on the East Asian summer monsoon in China. Monsoon Meteorology, C.-P. Chang and T. N. Krishnamurti, Eds., Oxford University Press, 60-92.

Tokinaga, H., Y. Tanimoto, S.-P. Xie, T. Sampe, H. Tomita, and H. Ichikawa, 2009: Ocean frontal effects on the vertical development of clouds over the western North Pacific: In situ and satellite observations. J. Climate, 22, 4241-4260.

Ueda, H., T. Yasunari, and R. Kawamura, 1995: Abrupt seasonal change of large-scale convective activity over the western Pacific in the northern summer. J. Meteor. Soc. Japan, 73, 795-809.

— velopment of the Asian-Northwest Pacific summer monsoon. J. Climate, 22, 649-669.

Wang, B., Ed., 2006: The Asian Monsoon. Springer-Praxis, 844 pp. _ - and LinHo, 2002: Rainy season of the Asian-Pacific summer monsoon. J. Climate, 15, 386-398. 
Watanabe, M., and M. Kimoto, 2000: Atmosphere-ocean thermal coupling in the North Atlantic: A positive feedback. Quart. J. Roy. Meteor. Soc., 126, 3343-3369.

— , and - 2001: Corrigendum. Quart. J. Roy. Meteor. Soc., 127, 733-734.

Wu, G., and Y. Liu, 2003: Summertime quadruplet heating pattern in the subtropics and the associated atmospheric circulation. Geophys. Res. Lett., 30, 1201, doi:10.1029/2002GL016209.

Xie, S.-P., and N. Saiki, 1999: Abrupt onset and slow seasonal evolution of summer monsoon in an idealized GCM simulation. J. Meteor. Soc. Japan, 77, 949-968.

K. Hu, J. Hafner, H. Tokinaga, Y. Du, G. Huang, and T. Sampe, 2009: Indian Ocean capacitor effect on Indowestern Pacific climate during the summer following El Niño. J. Climate, 22, 730-747.
Yamazaki, N., and T.-C. Chen, 1993: Analysis of the East Asian monsoon during early summer of 1979: Structure of the Baiu front and its relationship to large-scale fields. J. Meteor. Soc. Japan, 71, 339-355.

Yang, J., Q. Liu, S.-P. Xie, Z. Liu, and L. Wu, 2007: Impact of the Indian Ocean SST basin mode on the Asian summer monsoon. Geophys. Res. Lett., 34, L02708, doi:10.1029/ 2006 GL028571.

Yasunari, T., and T. Miwa, 2006: Convective cloud systems over the Tibetan Plateau and their impact on meso-scale disturbances in the Meiyu/Baiu frontal zone-a case study in 1998. J. Meteor. Soc. Japan, 84, 783-803.

Zhang, S.-P., S.-P. Xie, Q.-Y. Liu, Y.-Q. Yang, X.-G. Wang, and Z.-P. Ren, 2009: Seasonal variations of Yellow Sea fog: Observations and mechanisms. J. Climate, 22, 6758-6772. 